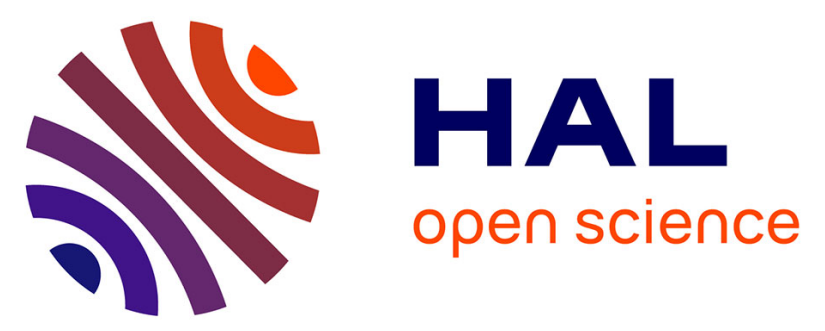

\title{
Direct dating of brittle extensional deformation contemporaneous of Neogene exhumation of the internal zones of the Rif Chain
}

Philippe Münch, Jacinthe Caillaud, Patrick Monie, O. Grauby, Michel Corsini, Julia Ricci, Adrien Romagny, Melody Philippon, Bruno Lanson, Ali Azdimousa, et al.

\section{To cite this version:}

Philippe Münch, Jacinthe Caillaud, Patrick Monie, O. Grauby, Michel Corsini, et al.. Direct dating of brittle extensional deformation contemporaneous of Neogene exhumation of the internal zones of the Rif Chain. Tectonophysics, 2021, 807, pp.228800. 10.1016/j.tecto.2021.228800 • hal-03175777

\author{
HAL Id: hal-03175777 \\ https://hal.science/hal-03175777
}

Submitted on 2 Nov 2021

HAL is a multi-disciplinary open access archive for the deposit and dissemination of scientific research documents, whether they are published or not. The documents may come from teaching and research institutions in France or abroad, or from public or private research centers.
L'archive ouverte pluridisciplinaire HAL, est destinée au dépôt et à la diffusion de documents scientifiques de niveau recherche, publiés ou non, émanant des établissements d'enseignement et de recherche français ou étrangers, des laboratoires publics ou privés.

\section{(ㅇ)(1) $\$$}

Distributed under a Creative Commons Attribution - NonCommercial - NoDerivatives 44.0 
Direct dating of brittle extensional deformation contemporaneous of Neogene exhumation of the internal zones of the Rif Chain

\author{
Münch Philippe a,*, Caillaud Jacinthe ${ }^{\text {b }}$, Monié Patrick a , Grauby Olivier ${ }^{\text {c }}$, Corsini \\ Michel d, Ricci Julia a, Romagny Adrien e, Philippon Melody f, Lanson Bruno g, \\ Azdimousa Ali h, Ben Moussa Abdelkhalak i, Arnaud Nicolas a
}

${ }^{a}$ Géosciences Montpellier, Université de Montpellier-CNRS-Université des Antilles, CC 060, place Eugène Bataillon, 34095 Montpellier cédex 5, France

b Université Littoral Côte d'Opale, Univ. Lille, CNRS, UMR 8187, LOG, Laboratoire d'Océanologie et de Géosciences, F 62930 Wimereux, France

${ }^{c}$ Aix-Marseille Université - UMR 7325 CINaM/CNRS, campus de Luminy, Case 913, 13288 Marseille Cedex 9, France

d Université Côte d'Azur, CNRS, Observatoire de la Côte d'Azur, IRD, Géoazur, 250, rue Albert Einstein, 06560 Sophia Antipolis, France

e 4, rue du Lavoir, 06340 Drap, France

${ }^{\mathrm{f}}$ Géosciences Montpellier, Université de Montpellier-CNRS-Université des Antilles, Campus de Fouillole, 97159 Pointe-à-Pitre, FWI, France

g Université Grenoble Alpes, Univ. Savoie Mont Blanc, CNRS, IRD, Univ. Gustave Eiffel, ISTerre, F-38000 Grenoble, France ${ }^{\text {h }}$

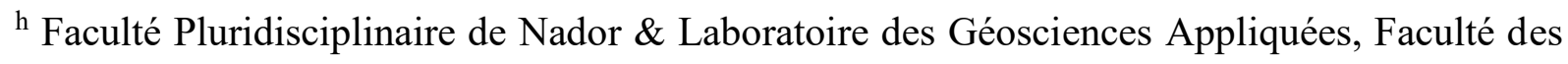
Sciences, Université Mohammed I, Oujda, Morocco

i Département de Géologie, Université Abdelmalek Esaadi, 93003 Tetuán, Morocco

\title{
Abstract
}

The brittle deformation of internal zones of the Rif chain, corresponding to the southern margin of the West Alboran Basin, is not or poorly dated because of the lack of stratigraphic constraints. We provide for the first time a direct dating of brittle deformation of internal zones of the Rif chain, in the Ceuta peninsula located in the westernmost part of the Gibraltar arc. ${ }^{40} \mathrm{Ar} /{ }^{39} \mathrm{Ar}$ illite ages from fault gouges in the footwall and hanging wall of the Ceuta Shear Zone range from $11.9 \pm 2.5 \mathrm{Ma}$ to $15.7 \pm 1.7 \mathrm{Ma}$ and from $14.7 \pm 0.1 \mathrm{Ma}$ to $18.9 \pm 0.8 \mathrm{Ma}$, respectively. In addition, (U-Th)/He apatite ages from both units have been measured. They are younger in the hangingwall ( $20-21 \mathrm{Ma})$ than in the footwall (14-19 Ma), which highlights 
slightly different cooling history. Thus, we interpret the illite ages to date growth of authigenic illite (1M polytype) during exhumation through the top few kilometers of the earth's surface.

This study of brittle deformation within the internal zones of the Rif chain reveals that an E-W directed extension lasted between $\sim 18-15$ Ma during the low temperature exhumation of Sebtide-Alpujárride units. From 15 to $11 \mathrm{Ma}$, the direction of extension shifted to NNWSSE and only minor steep normal faults. Brittle normal faulting occurred during a stage of slow cooling $\left(\sim 1-2^{\circ} \mathrm{C} / \mathrm{myr}\right)$ starting at $\sim 19 \mathrm{Ma}$ and coeval with exhumation processes within the uppermost levels of the continental crust. These new data emphasize a continuum of extensional deformation during the Burdigalian-Serravalian interval with an early E-W directed phase and then a NNW-SSE directed phase that match well the main subsidence pulses identified offshore in the neighboring West Alboran Basin.

Keywords: Fault gouge dating, ${ }^{40} \mathrm{Ar} /{ }^{39} \mathrm{Ar}$ dating, Low-T thermochronology, Brittledeformation, Rif chain

\section{1- Introduction}

Numerous studies have been conducted to elucidate the exhumation history of the internal zones of the Rif-Betic chain and their very rapid cooling towards surface temperatures since 21 Ma meets a large consensus (e.g. Zeck et al., 1992; Monié et al., 1994; Johnson, 1997; Platt et al., 1998, 2003; Hurford et al., 1999; Augier et al., 2005a; Vazquez et al., 2011; Azdimousa et al., 2013; Esteban et al., 2013; Romagny et al., 2014; Janowski et al., 2017). The

role of extension in the Neogene evolution of the Internal zones of the Rif-Betic chain and adjacent Alboran basin is also now widely recognized (e.g. Platt et al., 1989, 2005; Platt and Vissers, 1989; García-Dueñas et al., 1992; Jabaloy et al., 1993; Watts et al., 1993; Crespo-Blanc et al., 1994; Martínez-Martínez and Azañón, 1997; Vissers, 2012; Augier et al., 2013). However, the geodynamic context of extension is still debated: late orogenic extensional collapse (Dewey, 1988; Platt and Vissers, 1989), lithospheric delamination (Calvert et al., 2000) or back-arc extension in a westward retreating subduction (Jolivet et al., 2006). The timing of extension is closely related to the study of associated sedimentary deposits in the Betics and the Alboran basin but sedimentary basins are scarce in the Rif internal zones and only poor biostratigraphic constraints are available. Moreover, the extensional tectonics in the southwestern Alboran basin remains unclear and Neogene extensional structures are scarce (Do Couto et al., 2016). Direct dating of clay minerals from fault gouges associated with normal faults provides the unique opportunity to date the pervasive Neogene extensional deformation 
in the Rif internal zones (Morel, 1988; Chalouan et al., 2008; Romagny et al., 2014; El Ouaragli et al., 2016) which constitute the southern margin of the Western Alboran Basin (WAB). Such extensional brittle deformation may have accommodated the latest phases of low temperature exhumation of the Rif chain.

In crustal rocks, two major processes occur to form clay gouge during faulting: the comminution and neocrystallisation. The result is the formation of a mixture of two main mica polytypes: "detrital" illite/muscovite inherited from host rocks $\left(2 M_{l}\right)$ and authigenic illite $\left(1 M_{d}\right)$ newly formed during faulting episodes (van der Pluijm et al., 2001). 2M $M_{1}$ polytype is formed at temperature above $280^{\circ} \mathrm{C}$ (Velde, 1965 ; Srodon and Eberl, 1987) whereas $1 M_{d}$ polytype in the range $90-180^{\circ} \mathrm{C}$ with some occurrences at lower temperatures (synthesis in Haines and van der Pluijm, 2012). As illite is a K-rich phase, K-Ar and ${ }^{40} \mathrm{Ar} /{ }^{39} \mathrm{Ar}$ dating of authigenic illite in gouges allow direct dating of shallow faulting (van der Pluijm et al., 2001; Zwingman and Mancktelow, 2004; Solum et al., 2005; Clauer, 2013; Tsukamoto et al., 2020). However, it is exceptional to isolate a pure authigenic illite fraction and dating is most often performed on a mixture of both detrital and authigenic illites. Previous studies have shown that $2 M_{1}$ polytype amount decreases in favor of $1 M_{d}$ polytype with the grain size, as well as clay minerals $\mathrm{K}-\mathrm{Ar}$ and ${ }^{40} \mathrm{Ar} /{ }^{39} \mathrm{Ar}$ ages (e.g. Haines and van der Pluijm, 2008, 2010, 2012; Zwingman et al., 2010a; Viola et al., 2016). Thus, to get an age of authigenic illite in a gouge, the method consists ideally in the dating of different granulometric fractions with different relative proportions of the two polytypes from which the fault motion age is calculated using a two-end member mixing line approach (Pevear, 1999; van der Pluijm et al., 2001; Haines and van der Pluijm, 2008, 2010, 2012). Even in this ideal situation, the significance of the calculated age is not straightforward because it could represent a single fault motion or solely the last major fault motion from a more complex brittle deformation history (Solum et al., 2005; Haines and van der Pluijm, 2008). However, the interpretation of direct dating of fault gouges can be improved by combining with low temperature thermochronological investigations of host rocks that allow to better constrain the temperature of illite growth in the fault gouge (e.g. Parry et al., 2001; Tagami, 2012; Duvall et al., 2015; Ring et al., 2017).

The aim of this paper is to shed light on the Neogene brittle extensional tectonic events involved in the internal zones of the Rif and to determine their timing from the study of the Ceuta peninsula (Spain) located at the western tip of the Gibraltar arc. For this purpose, we performed the ${ }^{40} \mathrm{Ar} /{ }^{39} \mathrm{Ar}$ dating of illitic gouges from five normal faults and we combined it 
with $\mathrm{U}-\mathrm{Th} / \mathrm{He}$ dating of apatites from adjacent host rocks of the Sebtide-Alpujárride unit in order to situate faulting events during the cooling history through upper crustal levels.

\section{2- Geological setting}

Surrounding the Alboran basin, the Rif-Betic orogen develops along the Gibraltar arc (Fig. 1), shaped in the context of Africa-Eurasia convergence since the late Mesozoic. It is constituted by a pile of nappes thrusted onto the Guadalquivir and Gharb foreland basins and it can be divided into four major domains (e.g. Chalouan et al., 2008; Platt et al., 2013 and references therein):

- the external domain consisting of Triassic to Miocene sediments originating respectively from Iberian and African paleomargins, folded and thrusted during the Miocene.

- the Maghrebian flyschs unit, pinched in between external and internal domains, corresponding to Late Jurassic to Early Burdigalian siliciclastic series from the Neotethys basin (Bouillin et al., 1970; Guerrera et al., 2005; Luján et al., 2006; de Capoa et al., 2007; Azdimousa et al., 2019). This unit registered mainly compressional deformations related to the thrusting of internal zones onto external zones.

- the internal zones comprise from top to bottom : the "Dorsale Calcaire" made of Mesozoic to Cenozoic carbonates from the passive Alboran paleomargin, the GhomarideMalaguide complex corresponding to low-grade to non-metamorphic Paleozoic rocks with their Permo-Triassic sedimentary cover, the Sebtide-Alpujárride complex corresponding to high- to low-grade HT-LP metamorphosed Paleozoic rocks and the Nevado-Filábride complex, only exposed in the southeastern Betics, partly corresponding to a HP-LT metamorphic unit (e.g. Augier et al., 2005a; Booth-Rea et al., 2005; Platt et al., 2013). All these units are bounded by major thrusts. The Sebtide-Alpujárride complex experienced between 23 and 19 Ma a very rapid cooling, from $800 \pm 50{ }^{\circ} \mathrm{C}$ to $250 \pm 50{ }^{\circ} \mathrm{C}$ (e.g. Platt et al., 2003; Michard et al., 2006; Azdimousa et al., 2013; Esteban et al., 2013; Homonnay et al., 2018). This very rapid cooling is thought to correspond to a late stage post-orogenic thinning accommodated by the ductile then brittle exhumation of metamorphic rocks in internal zones. In Spain, the brittle deformation within the Malaguide and Alpujárride units started in early Miocene with top to the $\mathrm{N}$ extensional faulting after the reactivation of the Malaguide-Alpujárride contact as a detachment (Rossetti et al., 2005). A detrital sedimentation with Ghomaride-Malaguide derived clasts, the Ciudad Granada group corresponding to the Fnideq formation in Morocco, started within the 
western part of Rif-Betic internal zones during the late Oligocene-Aquitanian interval and may have recorded the onset of the brittle extensional deformation (Serrano et al., 2006; Hlila et al., 2008). This sedimentation lasted until the middle Burdigalian (i.e. the Viñuela group corresponding to the Sidi Abdeslam formation in Morocco) and both groups belong to the socalled "post-nappe" cover of internal zones (e.g. Chalouan et al., 2008). In Spain, the occurrence of Sebtide-Alpujárride crustal rock pebbles in conglomerates from the Viñuela group of Burdigalian age indicates that some parts of Alpujárride units were totally exhumed since Burdigalian time and fed the detrital sedimentation in basins developed in the internal zones and in the Alboran Sea (Monié et al., 1994; Comas et al., 1999; Serrano et al., 2006; Iribarren et al., 2009; Do Couto et al., 2016). This sedimentation was associated with a NNW-SSE directed extension that lasted until the Langhian in the Betics (Crespo-Blanc et al., 1994). However, deposits from the Sidi Abdeslam formation on the Moroccan margin are scarce (Serrano et al., 2006). Later on, in the Serravalian-Tortonian interval, brittle extensional events leaded to the development of the so-called 'intra-montane' basins in the Betic chain internal zones, particularly in the east, and affected both sedimentary basins and their basement (Sanz de Galdeano and Vera, 1991; Augier et al., 2005b; Meijninger and Vissers, 2006; Augier et al., 2013). In the Rif internal zones, only one small outcrop of middle-late Miocene marine sediments (Oued Dayr formation) is not precisely dated and proposed to be "no older than middle Langhian" or Tortonian in age, i.e. between 14.9 and 7.2 Ma (Zaghloul et al., 2010). Consequently, extensional brittle deformations that can be observed throughout the metamorphic basement of the Rif chain internal zones remain undated yet. During the middlelate Miocene period, the Rif-Betic chain internal zones underwent a cooling from $250 \pm 50{ }^{\circ} \mathrm{C}$ to $60 \pm 20^{\circ} \mathrm{C}$, at slower rates, corresponding to the LT exhumation of the basement rocks (Vazquez et al., 2011; Azdimousa et al., 2013; Romagny et al., 2014; Janowski et al., 2016). During the late Tortonian, extensional tectonics was followed by a regional compressional event throughout the Rif-Betic chain and the Alboran basin. At last, internal zones recorded a final uplift event during the late Pliocene (Morel, 1988; Braga et al., 2003; Cornée et al., 2014, 2016), associated with brittle extensional deformation and tilting towards the center of the Alboran sea of marginal basins corresponding to Pliocene-Recent rias (Morel, 1988; Romagny et al., 2014).

- the Alboran basin, which is floored by the Sebtide-Alpujárride unit, recorded the transition from extension (late Oligocene-Tortonian) to compression (late Tortonian-Present day) characterized by the inversion of some extensional features (e.g. Bourgois et al., 1992; Chalouan et al., 1997; Comas et al., 1999; Do Couto et al., 2016). The subsidence in the Alboran 
basin is very high since Oligocene, mainly in the West Alboran basin (up to $10 \mathrm{~km}$; Iribarren et al., 2009; Do Couto et al., 2016). There, such a subsidence has been proposed to be enhanced by the constant load of the underlying subducting slab during its westward retreat (Do Couto et al., 2016). The metamorphic basement from this basin experienced a rather similar thermal evolution to the onshore internal zones with a very rapid cooling from HT metamorphic conditions to $120^{\circ} \mathrm{C}$ between 20.5 and $19 \mathrm{Ma}$ followed by a slower cooling from 120 to $60{ }^{\circ} \mathrm{C}$ between 19 and $18 \mathrm{Ma}$ (Kelley and Platt, 1999; Comas et al., 1999; Hurford et al., 1999). The onset of the tectonic inversion and a contractional reorganization of the Alboran basin occurred during the Tortonian at around $9 \mathrm{Ma}$ (Do Couto et al., 2016). However, it is noticeable that, offshore Morocco, the post-Aquitanian brittle extensional structures are unclear and only, probably very late (Pliocene?), normal faults striking parallel to the coastline can be observed (Chalouan et al., 1997). In the western part of the WAB, Do Couto et al. (2016) showed that the contact between Burdigalian-Langhian sedimentary deposits and the metamorphic substratum does not display extensional structures. Serravalian $(\sim 12 \mathrm{Ma})$ brittle extensional structures have been described at site 976 in the northeastern part of the WAB and along the spanish coast (Comas and Soto, 1999) but are unkwown in the Rif internal zones. These reinforce the need to provide precise time constraints for brittle extensional deformations in adjacent coastal rifian internal zones despite the lack of associated onshore sedimentary basins.

\section{3- The Ceuta peninsula}

The Ceuta peninsula is the main locality of the Rif chain where the lowermost unit of the Sebtide complex is exposed: the orthogneiss from the Monte Hacho Lower Unit (MHLU; Kornprobst, 1974; Homonnay et al., 2018). It corresponds to the deeper unit of the Sebtide and the Ojen unit in the Betics (Fig. 2). In the Ceuta peninsula, the MHLU is overthrusted by the Ceuta Upper Unit (CUU; Homonnay et al., 2018), which is composed of a peridotite sliver itself overlain by a meta-sedimentary unit, along the Ceuta Shear Zone (CSZ). The meta-sedimentary unit of the CUU consists of granulitic and migmatitic paragneiss exhibiting a complex metamorphic history evolving from Variscan UHP/ UHT conditions $\left(4.3\right.$ to $7 \mathrm{GPa}$ and $1100{ }^{\circ} \mathrm{C}$ in Ruiz Cruz et al., 2012) to Alpine HP/HT conditions $\left(750-870{ }^{\circ} \mathrm{C}\right.$ and $\left.9-13 \mathrm{kbar}\right)$ then LP/HT conditions (650-750 ${ }^{\circ} \mathrm{C}$ and 3-5 kbar) (El Maz and Guiraud, 2001; Hommonay et al., 2008). The thrusting of the CUU occurred during a compressional phase before $28 \mathrm{Ma}$ (Homonnay et al., 2018). At last, all units underwent amphibolite to greenschist facies conditions (400-550 ${ }^{\circ} \mathrm{C}$ and 1-3 kbar) at around $21 \mathrm{Ma}$ (Homonnay et al., 2018). This last metamorphic event is 
associated with a ductile extensional event accommodated by NNW-SSE trending shear zones crosscutting the foliation of all metamorphic units and indicating a top-to-the-SW sense of shear. Moreover, the CSZ was reactivated as a detachment fault with a top-to-the-SW sense of shear. Syn-kinematic muscovites from newly formed shear zones within both CUU and MHLU and from the CSZ yield concordant ${ }^{40} \mathrm{Ar} /{ }^{39} \mathrm{Ar}$ ages of $\sim 21 \mathrm{Ma}$ such as all thermochronometers used in these metamorphic units (i.e. U-Th- $\mathrm{Pb}$ on monazite and xenotime, Ar-Ar on biotite; Homonnay et al., 2018). This ductile extensional event occurred under intermediate temperature-low pressure conditions probably in association with a major thermal event, recorded throughout the Alboran arc, and significant fluid circulations, responsible for total or partial recrystallization and resetting of minerals that provided ages around $21 \mathrm{Ma}$ regardless of the metamorphic assemblage they belong to (Homonnay et al., 2018). This extensional event has been proposed to be related to the opening of the Alboran basin in a back-arc position (Homonnay et al., 2018; El Bakili et al., 2020). However, the thermal evolution toward (sub-) surface temperatures is not documented yet and the brittle deformation, mainly extensional, that is also observable in the peninsula remains poorly studied and undated.

\section{4- Analytical procedures}

4.1- Mineralogy and polytype quantification

Nine gouge samples have been examined and then cleaned in order to remove clasts of host rock minerals and superficial weathering. First, a $\sim 1 \mathrm{~cm}^{3}$ volume of gouge was crushed and examined as random total powder to obtain the total mineralogical composition by X-ray Diffraction (XRD). Among nine gouges, only five samples were selected according to the amount of illite. The rest of material of the five selected samples was disaggregated using freezing and thawing cycles. This method was preferred to the classical grinding to avoid the creation of fine particles from coarse detrital minerals from the host rocks (e.g. quartz, feldspars and micas; Laverret et al., 2010). Then, samples were shaken mechanically in distilled water to obtain the suspension of clay particles. For each sample, we prepared four clay size fractions $(1-2 \mu \mathrm{m} ; 0.5-1 \mu \mathrm{m} ; 0.5-0.2 \mu \mathrm{m}$ and $<0.2 \mu \mathrm{m})$ without any chemical pre-treatment thanks to gravity sedimentation rate following the procedure of Moore and Reynolds (1989), except for the sample M10-30 for which we prepared only three fractions.

The XRD studies were carried out at the analytical platform RRXG of the University of Montpellier (France) equipped with a PANalytical X'Pert Pro X-ray Diffractometer $(45 \mathrm{kV}$; $25 \mathrm{~mA})$ with $\mathrm{Ni}$-filtered $\mathrm{Cu} \mathrm{K \alpha}$ radiation $(\lambda=1.5406 \AA)$ coupled to a $\mathrm{X}^{\prime}$ Celerator detector. 
Oriented clay aggregates were prepared from the evaporation of a clayey suspension on glass slides, and analyzed by XRD both air-dried (AD) and after ethylene-glycol (EG) treatment. Background stripping, diffraction peak indexing, mineral identification by comparison with the files of the Joint Committee on Powder Diffraction Standards (JCPD) and semi-quantitative analysis were carried out using the X'Pert data HighScore software (Table 1).

The illite polytypes were determined on randomly oriented size fractions over the 19$37^{\circ} 2 \theta$ angles with a step size of 0.02 [ ${ }^{\circ} 2 \mathrm{Th}$.] during a step time of $55 \mathrm{~s}$, from diagnostic peaks as described and recommended by Moore and Reynolds (1989, 1997)(Table 1). Illite polytype identification was based on comparisons with reference data for the $2 M_{1}$ type (Bailey, 1980; Brindley, 1980), and for the $1 M / 1 M_{d}$ type (Drits et al., 1993). Each polytype pattern (100\% of $2 M_{1}$ and $100 \%$ of $1 M$ ) characterized by previous distinct series of XRD reflections is calculated on the basis of a chemical and structural model (Drits et al., 1993; Zviagina et al., 2007). In this model, different parameters may be specified or adjusted (cis or trans vacancy, iron content, crystallite size) according to the better match of the data, in particular peak position and breadth. In this study, three end-members were used to model the gouge fractions: the $2 M_{1}$ polytype (detrital mica), the $1 M$-cv polytype (cis-vacant) and the $1 M$-tv polytype (trans-vacant) where the sum $(1 M-\mathrm{cv}+1 M-\mathrm{tv})$ corresponds to the authigenic illite.

For each gouge fraction, except sample SEB12-02, we performed morphological observations and TEM-EDX microanalyses from dispersed clay particles sedimented onto carbon-coated copper grids. Distinct granulometric fractions (coarse: $<2 \mu \mathrm{m}$, medium: $<0.5 \mu \mathrm{m}$ and fine: $<0.2 \mu \mathrm{m}$ ) were used in order to compare the morphology and mineralogy of particles of different sizes. A JEOL JEM 2011 TEM fitted with a X-Flash Silicon Drift Detector 5030 (Bruker) was used at the CINaM laboratory (Marseille, France) with the following parameters: magnification of $50000 \mathrm{x}, \sim 200 \mathrm{~nm}$ spot size, angular tilt of $20^{\circ}$ toward the detector, time constant of $60 \mathrm{kcp} . \mathrm{s}^{-1}$, energy range of $40 \mathrm{keV}$, and corrected counting time of 30 seconds. The smallest particles could be studied thanks to the $20 \mathrm{~nm}$ beam diameter and a constant beam density close to $63.5 \mathrm{pA} . \mathrm{cm}^{-2}$. The Bruker AXS MET line mark data quantification procedure, close to the Cliff and Lorimer method (Cliff and Lorimer, 1975), including background subtraction (Bremsstrahlung calculation), Gaussian deconvolution, and k factor corrections (Berthonneau et al., 2014) was applied previously on acquired EDX spectra to quantify major elements (O, Na, Mg, Al, Si, K, Ca, and Fe). The structural formulas of micas (muscovite, illite) and derived-clay minerals (I/S and smectite) were calculated on the basis of $11 \mathrm{O}$ per formula and with the $\mathrm{Fe} 3+$ state for the iron (online supplementary material). 


\section{2- ${ }^{40} \mathrm{Ar} /{ }^{39} \mathrm{Ar}$ dating}

The sample preparation was performed without any chemical treatment to avoid any impact on the structure of the phyllosilicates. In order to evaluate the amount of recoiled ${ }^{39} \mathrm{Ar}$ during samples irradiation, all granulometric fractions $(1-2 \mu \mathrm{m}, 0.5-1 \mu \mathrm{m}, 0.5-0.2 \mu \mathrm{m},<0.2$ $\mu \mathrm{m}$ and the bulk) have been compacted mechanically and then about 1 to $2 \mathrm{mg}$ of these fractions were encapsulated in quartz tubes prior to irradiation. Moreover, each quartz tube of about 0.1 $\mathrm{cm}^{3}$ is heated and evacuated under vacuum to remove air contamination on the quartz surface at $10^{-8}$ bar prior to sample loading (Dong et al., 1995; Smith et al., 1993). After loading and before sealing, the tube is pumped during $12 \mathrm{~h}$ with a turbo-pump and the pressure is controlled with a gauge between the pump and the tube.

Samples were irradiated for $32 \mathrm{~h}$ in the core of the Triga Mark II nuclear reactor of Pavia (Italy) with several aliquots of the Taylor Creek sanidine standard as flux monitor (28.619 \pm 0.034 Ma in Renne et al., 2010). Argon isotopic interferences on $\mathrm{K}$ and Ca were determined by irradiation of $\mathrm{KF}$ and $\mathrm{CaF}_{2}$ pure salts from which the following correction factors were obtained: $\left({ }^{40} \mathrm{Ar} /{ }^{39} \mathrm{Ar}\right)_{\mathrm{K}}=0.00969 \pm 0.00038, \quad\left({ }^{38} \mathrm{Ar} /{ }^{39} \mathrm{Ar}\right)_{\mathrm{K}}=0.01297 \pm 0.00045$, $\left({ }^{39} \mathrm{Ar} /{ }^{37} \mathrm{Ar}\right)_{\mathrm{Ca}}=0.0007474 \pm 0.000021$ and $\left({ }^{36} \mathrm{Ar} /{ }^{37} \mathrm{Ar}\right)_{\mathrm{Ca}}=0.000288 \pm 0.000016$. Atmospheric ${ }^{40} \mathrm{Ar}$ was estimated using a value of the initial ${ }^{40} \mathrm{Ar} /{ }^{36} \mathrm{Ar}$ ratio of $298.56 \pm 0.31$ (Lee et al., 2006).

Argon analyses were performed at Géosciences Montpellier (France) with an analytical system consisting of: (a) a UV laser used to drill the quartz tubes and an infra-red laser for the step-heating experiments, (b) a lenses system for UV beam focusing, (c) a steel sample chamber, maintained at $10^{-8}-10^{-9}$ bar, with a copper plate holding 5 tubes, (d) an inlet line for purification of gases including two $\mathrm{Zr}-\mathrm{Al}$ getters and a cold trap, (e) a multi-collector mass spectrometer (Argus VI from Thermo-Fisher). After irradiation, and before laser heating of the samples, the quartz tubes were drilled with the UV laser and the amount of ${ }^{39} \mathrm{Ar}$ lost due to recoil during fast neutron interaction was measured for each fraction using the multi-collector mass spectrometer. For each fraction, we calculated a Total Gas Age (TGA) by adding the recoiled ${ }^{39} \mathrm{Ar}$ to the amount of ${ }^{39} \mathrm{Ar}$ released during step-heating (Table 2). Therefore, TGA, which is equivalent to a $\mathrm{K}-\mathrm{Ar}$ age, is taken as the representative age of each fraction following van der Pluijm et al. (2001). The ArArCalc softwareC v2.5.2 (Koppers, 2002) was used for data reduction and plotting. All ages are given with errors at the $2 \sigma$ interval (detailed results are given as online supplementary material).

\section{3- U-Th/He analysis}


We performed Apatite U-Th/He (AHe) dating on two samples from the CUU and two from the MHLU (Table 3). For AHe dating, 3-5 inclusion free single crystals of apatite were packed in platine tubes, placed under vacuum and heated at $900^{\circ} \mathrm{C}$. After helium extraction, aliquots were retrieved for $\mathrm{U}$ and Th measurements by ICP-MS. Single apatite crystals have been analyzed at Géosciences Montpellier (France) following the detailed procedure described in Wu et al., (2016). Inverse thermal history modelling was performed with the QTQt software (Gallagher et al., 2009) and we used the helium thermal diffusion model for apatite of Gautheron et al. (2009).

\section{4- Paleostress tensors}

This study presents a structural data set consisting of measurements of fractures, faults associated kinematics criteria, acquired over 7 sites located on the dated fault gouges and neighboring areas. We used the right dihedron method to inverse the fault kinematics and obtain the paleostress tensor using WinTensor software (Angelier, 1979; Angelier \& Mechler, 1977; Delvaux and Sperner, 2003). WinTensor allows the rotational optimization of the obtained tensor by performing iterative tests on the tensors in order to minimize a misfit function (Delvaux and Sperner, 2003). We performed these inversions with a set of data consisting of the fault strike, dip, plunge of the striae and kinematic criteria.

\section{5- Results}

\section{1- Brittle deformation in Ceuta}

Despite slight late compressional deformations evidenced by open folding of the whole metamorphic pile of Ceuta (including greenschist facies foliation developed in extensional shear zones) and scarce small strike-slip faults, the latest deformation in the Ceuta peninsula is mainly represented by steep brittle normal faults crosscutting all previous ductile structures (foliations, folds and shear zones). Some normal faults exhibit late strike slip reactivation. Within MHLU, normal faults are mainly discrete faults trending NE-SW and E-W with very thin $(<0.5 \mathrm{~cm})$ individual gouge layers exhibiting slickensides (Fig. $3 \mathrm{~A}$ and B). In CUU, normal faults are trending NW-SE and NE-SW with up to c. 1.5-meter-thick fault core (sensu Caine et al., 1996) characterized by the occurrence of decimetric gouge layers and foliated clayrich phyllonites with $\mathrm{S} / \mathrm{C}$ structures (Fig. $3 \mathrm{C}$ and $\mathrm{D}$ ). The thickness of the fault core is thought to be positively correlated to the displacement (e.g. Wibberley et al., 2008), so such differences may result from various amount of fault throw. The lithological differences between the two units (CUU paragneisses are much more rich in biotite and muscovite than MHLU 
orthogneisses which are richer in feldspars) and the development of a pervasive foliation only in CUU may also account for such differences. For the three sites within MHLU, the paleostress tensor corresponds to a subhorizontal extension $(\sigma 3)$ trending NNW-SSE with a subvertical maximum compression axis $(\sigma 1)$ characteristic of a pure extensional stress field (Fig. 2). In CUU, the paleostress tensor obtained from four sites in the vicinity of other dated gouges shows a subhorizontal extension $(\sigma 3)$ E-W directed with a subvertical maximum compression direction $(\sigma 1)$ (Fig. 2). However, the absolute and relative timing of brittle deformations from the two structural units (MHLU and CUU) remains unknown. Only direct dating of these deformations can provide chronological constraints for the brittle deformation affecting the internal zones of the Rif, and consequently for the adjacent WAB, between the AquitanianBurdigalian transition and the Pliocene. We thus selected two and three gouge samples along pure normal faults (without any evidence for strike slip reactivation) within MHLU and CUU, respectively.

\section{2- Gouges mineralogy}

XRD patterns on the bulk gouge samples show three major minerals: quartz, chlorite and mica (muscovite/illite). The M10-30 bulk sample is devoid of chlorite. SEB 12-02 and M10-29 bulk samples contain also some calcite $(4 \%)$ and albite $(15 \%)$ respectively. Semi-quantitative composition reveals that relative mica (muscovite/illite) content varied from $12 \%$ to $23 \%$ of total mineralogy in the five samples (Table 1). Parallel-oriented clay mineral XRD analyses reveal that, for all samples, the coarse mineral (quartz and feldspar) content decreases with the grain-size fraction as evidenced by the progressive disappearance of characteristic peaks. In all samples, variable amounts of chlorite coexist with illite/muscovite, except for sample M10-30 in which solely illite/muscovite occurs. When chlorite is present, its amount tends to decrease with the size of the fraction (Fig. 4). In the M10-29, SEB12-02 and CEU12-15 XRD patterns, we also evidenced some Illite/Smectite (I/S) minerals in addition to illite (Table 1). The swelling after the EG solvation is very weak and indicates that the amount of expandable component (smectite) in the $\mathrm{I} / \mathrm{S}$ is very low, i.e. $<10 \%$ (Moore and Reynolds, 1989). In the M10-29 sample, we also identified some minor amount of smectite, especially in $<0.2$ and $<0.5 \mu \mathrm{m}$ fractions, together with illite, I/S (10,9 $\AA$ in AD state) dominated by illite layers $(90 \%)$ and chlorite, by order of decreasing abundance (Fig. 4). The Scherrer equation gave decreasing illite crystal sizes with the decreasing grain size fraction (Table 1): about 226-479 $\AA$ in the 1-2 $\mu \mathrm{m}$ fraction, $143-428 \AA$ in the $0.5-1 \mu \mathrm{m}, 74-333 \AA$ in the $0.2-0.5 \mu \mathrm{m}, 98-251 \AA$ in the fraction 
$<0.2 \mu \mathrm{m}$. HRTEM and Fast Fourier Transform (FFT) also allow distinguishing various clay minerals in the different grain size fractions and were complemented by EDX micro-analyses (data available in online supplementary material). Muscovite crystals appear as isolated rigid laths whereas I/S or illite occurs in fluffy aggregates of fine individual crystallites (Fig. 5). The coarse fraction is dominated by tetrahedral charge bearing minerals such as muscovite (charge 1) and illite (charge 0.8-0.9), while the fine fraction contains additional clay minerals such as I/S and, in sample M10-29 only, smectite (charge 0.2-0.8)(Fig. 5). It is noticeable that in sample M10-30, we evidenced some rare I/S and beidellitic smectite with EDX micro-analyses whereas they were not detected in XRD. The relative abundance of $2 M_{1}$ and $1 M$ polytypes shows that $1 M$ polytype increase with the decreasing grain/crystal size indicating the decrease in the proportion of detrital muscovite and the correlative increase of authigenic illite (Table 1). In samples M10-29, CEU12-03 and M10-30, detrital muscovite (2Ml polytype) is dominant in the coarsest fraction and decreases down to $30 \%$ in the finest fraction whereas authigenic illite ( $1 \mathrm{M}$ polytype) is very dominant in all fractions in samples CEU12-15 and SEB12-02. Authigenic I/S with dominant illite layers (90\%) has also been detected in sample SEB12-02, CEU12-15 and M10-29 but illite remains the major authigenic component.

\section{3- ${ }^{40} \mathrm{Ar} /{ }^{39} \mathrm{Ar}$ fault gouge ages}

The ${ }^{40} \mathrm{Ar} /{ }^{39} \mathrm{Ar}$ age spectra of clay fractions in fault gouges from the MHLU and CUU in the Ceuta peninsula are shown in Figure 6 and the TGAs and ${ }^{39} \mathrm{Ar}$ recoil amounts are summarized in Table 2 for both bulk samples and each size fraction (detailed results are given in online supplementary material). The majority of age spectra exhibit the typical shape described by Dong et al. (1995) with a staircase shape in the first steps (low extraction temperatures) followed by a relatively flat shape and then frequently an age drop in last steps (highest extraction temperatures). Some coarser clay fractions display a saddle-shape age pattern after the initial age increase, followed by a series of more or less consistent apparent ages. A few age spectra show an age increase at the end of degassing, for a small amount of ${ }^{39} \mathrm{Ar}$ released (2-3\%). Such age spectra are usually interpreted to reflect i) mixtures of grains with different ages, ii) variable retentivity between authigenic and detrital illites, iii) ${ }^{39} \mathrm{Ar}$ recoil effects (Dong et al., 1995) and iv) possible excess argon contamination. Their meaning is discussed below in the light of the corresponding TGAs and amount of ${ }^{39} \mathrm{Ar}$ recoil.

For the bulk samples, the percentage of ${ }^{39} \mathrm{Ar}$ recoil varies between ca. 6 and $8.6 \%$ and Total Gas Ages (TGA) vary between $19.86 \pm 0.09$ and $22.05 \pm 0.09 \mathrm{Ma}$ (Table 2). Therefore, bulk sample TGAs are younger or concordant with the mean age of host rocks muscovite and 
biotite at 21.2 $\pm 0.7 \mathrm{Ma}$ (Homonnay et al., 2018), or slightly younger (spectra and detailed results are given as online supplementary material).

For the different grain size fractions, ${ }^{39} \mathrm{Ar}$ recoil increases with the decreasing size of clay fractions (Table 2), consistently with an increase of surface-to-volume area of cristallites. The amount of recoiled ${ }^{39} \mathrm{Ar}$ ranges from 12 to $32 \%$ of the total ${ }^{39} \mathrm{Ar}$ released and does not show a systematic correlation with the $1 M$ polytype content or crystallite thickness. For the five samples, TGA progressively decreases with the fraction size, consistently with the decreasing abundance of $2 M_{l}$ polytype (detrital illite/muscovite). For all the fractions, TGAs are younger than the mean age of $21.2 \pm 0.7 \mathrm{Ma}$ for metamorphic mica in host-rocks (Homonnay et al., 2018), with the exception of the two coarser fractions of sample CEU12-03 that provide TGAs of 24-25 Ma and very distorted age spectra with apparent ages up to $60 \mathrm{Ma}$.

To calculate the age of authigenic illite, we used the "illite age analysis method" (Pevear, 1999; van der Pluijm et al., 2001). In this method, a mixing line is constructed assuming an ideal binary mixing of inherited and authigenic illites. TGA is then linearly proportional to the amount of $2 M_{1}$ polytype (or $1 M$ polytype). In this mixing model, the upper intercept with the age axis gives the age of the inherited component and the lower intercept, at $0 \%$ of $2 M_{1}$ polytype, indicates the age of the pure authigenic component ( $1 M$ polytype).

Therefore, for each gouge sample, we plotted the TGA against the $2 M_{1}$ polytype percentage of each size fraction. For sample CEU12-03, we rejected the anomalous TGAs of 0.5-1 and 1-2 $\mu \mathrm{m}$ fractions that are much older than the age of inherited muscovite (Table 2). Intercept ages for $100 \%$ of $1 M$ authigenic illite, with in some cases minor $\mathrm{I} / \mathrm{S}$ with $>90 \%$ illite layers, are estimated at 16.0 $\pm 0.1 \mathrm{Ma}$ (CEU 12-03), $17.9 \pm 0.8 \mathrm{Ma}$ (SEB12-02) and 18.9 \pm 0.8 $\mathrm{Ma}(\mathrm{CEU} 12-15)$ in the CUU and at $11.9 \pm 2.5 \mathrm{Ma}(\mathrm{M} 10-30)$ and $15.7 \pm 1.7 \mathrm{Ma}(\mathrm{M} 10-29)$ in the MHLU (Fig. 7).

\section{3- Low temperature thermochronology and cooling history}

AHe mean ages for apatite from samples in the CUU are slightly younger, i.e. $14.4 \pm$ 0.9 and 18.6 $\pm 2.5 \mathrm{Ma}$, than in the MHLU, i.e. $20 \pm 1.2$ and 20.9 $\pm 1.8 \mathrm{Ma}$ (Table 3). This is consistent with their relative structural situation regarding the CSZ thrust. Indeed, the MHLU is located in the footwall of the CSZ and was cooled earlier than the CUU, which is located in its hanging wall. AHe ages have been used to reconstruct the thermal history of both units with QTQt software that allows modelling time-temperature paths that are consistent with thermochronometric data and independent geologic and thermochronologic constraints. In each unit, all samples were at the same altitude allowing us to model all apatite grains from the two 
samples at the same time. We use the mean age of the muscovite from host rocks as a thermochronologic constraints. The thermal modelling of the AHe ages from the two units indicates that MHLU should have passed through the Partial Retention Zone (PRZ) earlier than CUU (Fig. 8), consistently with the difference of AHe ages between the two units. The thermal history of both units clearly shows that after a period of rapid cooling, the internal zones were slowly cooled towards surface temperatures since $\sim 19$ Ma.

\section{6- Discussion}

\section{1- Interpretation of authigenic illite ages}

Direct dating of fault gouges in the uppermost kilometers of the crust with the "illite age analysis method" based on $\mathrm{K} / \mathrm{Ar}$ or ${ }^{40} \mathrm{Ar} /{ }^{39} \mathrm{Ar}$ dating (Pevear, 1999; van der Pluijm et al., 2001) developed since the end of the 1990's (e.g. Yaglan et al., 2002; Zwingmann and Mancktelow, 2004; Haines and van der Pluijm, 2008, 2012; Zwingmann et al., 2010a; Haines et al., 2016; Viola et al., 2016; Ring et al., 2017; Tsukamoto et al., 2020). In Ceuta, our illite age analysis yield ages ranging from $18.9 \pm 0.8$ Ma to $11.9 \pm 2.5$ Ma for the authigenic component.

However, we obtained spectra of some coarse fractions exhibiting a typical saddle shape for the high temperature steps, i.e. after the staircase increase of apparent ages from zero, and in some cases the TGA of these fractions is older than the mean age of muscovite from the metamorphic host rocks. The shape of the spectra may be interpreted in terms of excess of radiogenic ${ }^{40} \mathrm{Ar}$ in these fractions (McDougall and Harrison, 1999). This ${ }^{40} \mathrm{Ar}$ in excess probably originated from inherited minerals because these spectra were only obtained for coarser fractions. Indeed, muscovite and chlorite inherited from greenschist facies host rocks are more abundant in coarse fractions (Table 1) and ${ }^{40} \mathrm{Ar}$ excess is very common for metamorphic muscovite. However, ${ }^{40} \mathrm{Ar}$ in excess could also originate from fluids during the growth of authigenic illites. Even if we use the TGA for the illite age analysis, and not a plateau age as it is done for minerals formed at higher temperatures, the shape of the spectra allows detecting excess of radiogenic ${ }^{40} \mathrm{Ar}$ and appreciating the contribution of the various components of dated mixtures. In a first stage, we rejected from the illite age analysis only TGA older than the mean age of muscovite from host rocks (two coarse fractions from sample CEU12-03) because they are clearly anomalous. However, the spectra of coarse fraction from the sample M10-30 and CEU12-15 (1-2 $\mu \mathrm{m}$ and 1-2 $\mu \mathrm{m}$ and 0.5-1 $\mu \mathrm{m}$, respectively) have a saddle shape with individual step ages up to $40 \mathrm{Ma}$ (Fig. 7) whereas their TGA are younger than, or concordant to, the mean age of muscovite from host rocks $(21.2 \pm 0.7 \mathrm{Ma}$; Hommonay et al., 
2018). Therefore, these experiments should be also excluded from the illite age calculation of these samples. In sample CEU-15, the two fine fractions are composed of $100 \% 1 M$ polytype and yield concordant ages. The mean age of these two experiments $(18.1 \pm 0.8 \mathrm{Ma})$ is thus considered as the age of the pure authigenic component in CEU12-15, instead of 18.9 Ma. In sample M10-30, rejecting the age of the fraction 1-2 $\mu \mathrm{m}$ from the illite age analysis yield an age of 11.1 instead of 11.9 Ma. This highlights the efficiency of ${ }^{40} \mathrm{Ar} /{ }^{39} \mathrm{Ar}$ step heating technique to date mixed phase of inherited and neo-formed illite. Indeed, with the K-Ar method we would not have been able to detect ${ }^{40} \mathrm{Ar}$ excess especially in case where the age of the detrital component is unknown.

Within fault zones, $1 M_{d}$ illite is generally estimated to form in a temperature range of $60-180^{\circ} \mathrm{C}$ and illite-rich illite/smectite in rather a similar temperature range between $\sim 90$ $155^{\circ} \mathrm{C}$ with some occurrences at temperatures $<50^{\circ} \mathrm{C}$ (synthesis in Haines and van der Pluijm, 2012). A growing number of studies using $\mathrm{K} / \mathrm{Ar}$ or ${ }^{40} \mathrm{Ar} /{ }^{39} \mathrm{Ar}$ dating of authigenic illite from fault gouges coupled with low temperature fission track thermochronology in host rocks showed that $1 M_{d}$ illite growth occurred at the same time as the host rocks cooled through the partial annealing zone of apatite, i.e. $110-80^{\circ} \mathrm{C}$ (Parry et al., 2001; Sinclair et al. 2005; Siebel et al., 2010; Zwingmann et al., 2010b; Duvall et al., 2011; Löbens et al., 2011; Rahl et al., 2011). Thus, authigenic illite or I/S growth occurs while host rocks are exhumed at shallow depths, between $<2$ and $5 \mathrm{~km}$ (Haines and van der Pluijm, 2012). In Ceuta, it appears that authigenic illite, and associated minor I/S, grew in fault core while host rocks were exhumed mainly through the Partial Retention Zone (PRZ) of He within apatite (Fig. 9). Moreover, illite ages from the Ceuta Shear Zone footwall (MHLU) are slightly younger than in the hanging wall (CUU), i.e. 11.1-15.7 Ma and 14.7-18.1 Ma, respectively. This suggests that extensional E-W directed extension occurred before N-S directed one. This E-W directed brittle extension appears consistent with the previous $(\sim 21 \mathrm{Ma})$ ductile E-W stretching with a top to the west sense of shear (Homonnay et al., 2018) and thus suggests a continuum of deformation while the rock pile was exhumed across the brittle-ductile transition. From thermal histories, it appears that the E-W directed extension within the CUU occurred at slightly higher temperatures than the N-S directed extension within the MHLU and thus at greater depth. This is consistent with the larger fault core zones and associated gouges observed in the CUU than in the MHLU. Our results may suggest that the illite growth in fault cores from the Ceuta peninsula occurred while rocks were exhumed at shallow depths, $<2 \mathrm{~km}$. However, the temperatures of illite growth may have been higher than those predicted by thermal modelling of host rocks apatites in relation with shear heating and fluid circulations within fault zones. 


\section{2- Regional implications}

The latest NNW-SSE trending ductile extensional shear zones developed at $\sim 21 \mathrm{Ma}$ in the Ceuta peninsula under P-T conditions of $390-550{ }^{\circ} \mathrm{C}$ and 1-3 kbar (Homonnay et al., 2018). At this time, the internal zones were very rapidly cooled down to ca. $400^{\circ} \mathrm{C}$ and underwent ductile deformation highlighted by the development of a greenschist foliation, newly-formed extensional shear zones and the reactivation of the Ceuta Shear Zone (CSZ) as a ductile detachment fault. To the West and Southwest of the Ceuta some post-nappe sedimentary deposits from both Fnideq and Sidi Abdeslam formations are exposed (El Kadiri, 2000; Hlila et al., 2008). The onset of post-nappe sedimentation is dated from the late Oligocene (Fnidek formation; Feinberg et al., 1990). Basal conglomeratic deposits rest unconformably on Ghomaride-Malaguide units and are quartz-dominated with only some Ghomaride-Malaguide derived clasts (Hlila et al., 2008). This suggests that the Sebtide-Alpujárride units were not exhumed to the surface at this time in accordance with the modeled thermal history of CUU and MHLU in the Ceuta peninsula (Fig. 9). Within post-nappe basins of the Rif internal zones, the oldest known syn-sedimentary extensional deformation may have occurred during the deposition of the late Oligocene-latest Aquitanian Fnidek formation (Serrano et al., 2006; Hlila et al., 2008), and is thus prior to the oldest brittle deformation that we evidenced in the metamorphic basement.

Hlila et al. (2008) pointed the lack of clast derived from Sebtide-Alpujárride units within the Burdigalian Sidi Abdeslam formation. This is again in agreement with the modeled thermal history for the Sebtides units from the Ceuta peninsula (Fig. 9). However, the slightly different thermal histories of MHLU and CUU suggest that during early Burdigalian CSZ was reactivated as a low angle detachment fault accommodating E-W extension. Similarly, the contact between the Sebtide-Alpujárride and Ghomaride-Malaguide units were reactivated during early Miocene brittle extensional phases (Lonergan and Platt, 1995; Augier et al., 2005a; Platt et al., 2005; Rossetti et al., 2005; Do Couto et al., 2016). The E-W directed brittle extensional deformations recorded within the metamorphic basement of the Rif chain may correspond to the extensional pulse deduced from the acceleration of the subsidence in the neighboring WAB during the Burdigalian (Comas et al., 1999; Iribarren et al., 2009; Do Couto et al., 2016)(Fig. 10). Moreover, this E-W directed extension is consistent with the mainly E$\mathrm{W}$ direction of extension in the Alboran domain during the Burdigalian (Jolivet et al., 2006)(Fig. 10). However, the lack of early-middle extensional structures along the offshore Moroccan margin has been underlined (Do Couto et al., 2016) and the Burdigalian brittle 
structures from the Ceuta peninsula are the main records of early Miocene brittle extension on the southern margin of the WAB. Later on, the sedimentation almost ceased in the Rif internal zones and resumed mainly during the marine Pliocene infilling of coastal rias (Cornée et al, 2014; Romagny et al., 2014).

We evidenced slightly younger normal faults in the MHLU indicating a NNW-SSE extension that we dated between 15.7 and 11.1 Ma (Langhian-early Tortonian). At Oued Dayr, $31 \mathrm{~km}$ south from Ceuta, some scarce middle Langhian? or Tortonian? marine sediments (Oued Dayr formation; Fig. 10) were deposited during a syn-sedimentary NNW-SSE directed extensional event (D0 in El Ouaragli et al., 2016). Therefore, we propose that the brittle normal faults affecting both the basal Oued Dayr formation and the metamorphic basement in Ceuta correspond to the main Langhian-Serravalian extensional episode recorded in the WAB (Comas and Soto, 1999; Comas et al., 1999; Suades et al., 2013; Do Couto et al., 2016) but also in the Betics (Crespo-Blanc et al., 1994; Augier et al., 2013; Martínez-Martínez and Azañón, 1997)(Fig. 10). In the northern WAB, at DSDP site 976, Comas and Soto (1999) evidenced a main syn-sedimentary extensional deformation that is Serravalian in age. On the offshore Spanish margin, Suades et al. (2013) evidenced a NW-SE to N-S extension from Langhian to early Tortonian. However, no clear extensional middle Miocene deformation was evidenced in southern WAB (Do Couto et al., 2016). In the Rif, the weak character of this middle Miocene extension and the scarcity of associated sedimentary basins may illustrate the shifting of depocentres towards the center of the WAB where the subsidence was progressively concentrated (Comas et al., 1999; Iribarren et al., 2009; Do Couto et al., 2016). After the Serravalian, extensional tectonic almost ceased and the WAB is proposed to have behaved as a sag basin (Do Couto et al., 2016). At Oued Dayr, El Ouaragli et al. (2016) evidenced a postdepositional NW-SE to N-S directed compression thought to be Serravalian whereas, in Ceuta, we only observed extensional deformation from Burdigalian to early Tortonian.

The latest deformation event observed in the Ceuta peninsula corresponds to a strikeslip reactivation of normal faults and may be considered Tortonian in age. This tectonic inversion is consistent with the contractional reorganization described in the WAB and the Betics where it is dated from late Tortonian (Sanz de Galdeano and Vera, 1992; Comas et al., 1999; Augier et al., 2013; Do Couto et al., 2016). Late compressional deformation at Oued Dayr (D1-D3 in El Ouragli et al., 2016) could be consistent with these deformations or with midlate-Miocene gravity driven tectonics observed in the WAB (Do Couto et al., 2016).

To sum up, the Sebtide units in Ceuta underwent a ductile extension during Aquitanian, then two main brittle extensional events during the Burdigalian-early Tortonian and finally a 
Tortonian tectonic inversion. Since the early Burdigalian ( $\sim 19 \mathrm{Ma})$ they cooled slowly $(\sim 1-$ $2^{\circ} \mathrm{C} / \mathrm{myr}$ ) during the final exhumation of internal zones. However, the whole cooling history in Ceuta appears faster than in the WAB where metamorphic rocks from the basement cooled below $60^{\circ} \mathrm{C}$ at $18.3 \mathrm{Ma}$ (Comas et al., 1999) and than that of the Beni Bousera massif in the Rif that cooled below $40^{\circ} \mathrm{C}$ at $14 \mathrm{Ma}$ (Azdimousa et al., 2013; Romagny et al., 2014). This is peculiarly obvious for MHLU which represents the deepest part from the Sebtide-Alpujárride units that were cooled below $60-40^{\circ} \mathrm{C}$ at $\sim 19 \mathrm{Ma}$. This suggests that exhumation of SebtideAlpujárride units could have been earlier in the westernmost part of internal zones but further works are necessary to ascertain this hypothesis.

\section{7- Conclusion}

This study highlights the efficiency of the ${ }^{40} \mathrm{Ar} /{ }^{39} \mathrm{Ar}$ age analysis of authigenic illite from fault gouges combined with LT thermochronometry (AHe ages) that allowed us:

- dating mixed phases of inherited and neo-formed illite thanks to a cautious use of the illite age analysis method. Indeed, we show that it is possible to evidence some ${ }^{40} \mathrm{Ar}$ excess within inherited component, that would not have been possible with K-Ar method.

- reconstructing of the Burdigalian-early Tortonian brittle extensional tectonic history of the Sebtide-Alpujárride metamorphic rocks from the Rif internal zones despite the lack of associated sedimentary deposits. This history helps to constrain the tectonic history of the southern margin of the $\mathrm{WAB}$ where the extensional deformation is unclear on seismic lines.

- reconstructing of the thermal history of the westernmost part of internal zones of the Rif-Betic chain. This history reveals that after a rapid cooling until $60-40^{\circ} \mathrm{C}$ at $19 \mathrm{Ma}$, the internal zones were cooled very slowly $\left(\sim 1-2^{\circ} \mathrm{C} / \mathrm{myr}\right)$ representing exhumation within the uppermost 1-2 kilometers of the continental crust.

\section{ACKNOWLEDGEMENTS}

We thank Arthur Iemmolo for his technical assistance during ${ }^{40} \mathrm{Ar} /{ }^{39} \mathrm{Ar}$ analysis and $\mathrm{D}$. Granier for XRD measurements at the analytical platform RRXG of the University of Montpellier.

\section{8- Bibliography}


Achalhi, M., $\quad$ h, P., Cornée, J.J., Azdimousa, A., Melinte-Dobrinescu, M., Quillévéré, F., Drinia, H., Fauquette, S., Jiménez-Moreno, G., Merzeraud, G., Moussa, A.B., El Karim, Y., Feddi, N., 2016. The late Miocene Mediterranean-Atlantic connections through the North Rifian Corridor: new insights from the Boudinar and Arbaa Taourirt basins (northeastern Rif, Morocco). Palaeogeography Palaeoclimatology Palaeoecology, 459, 131-152.

Angelier, J., 1979. Determination of the mean principal directions of stresses for a given fault population. Tectonophysics, 56(7), 17-26.

Angelier, J., and Mechler, P., 1977. Sur une méthode graphique de recherche des contraintes principales également utilisable en tectonique et en séismologie: La méthode des dièdres droits. Bulletin de la Société Géologique de France, 7(XIX nº6), 1309-1318.

Augier, R., Agard, P., Monié, P., Jolivet, L., Robin, C., Booth-Rea, G., 2005a. Exhumation, doming and slab retreat in the Betic Cordillera (SE Spain): in situ 40Ar/39Ar ages and $\mathrm{P}-\mathrm{T}-\mathrm{d}-$ t paths for the Nevado-Filabride complex. J. Metamorph. Geol. 23, 357-381.

Augier, R., Jolivet, L., Robin, C., 2005b. Late orogenic doming in the Eastern Betic Cordilleras: final exhumation of the Nevado-Filabride complex and its relation to basin genesis. Tectonics 24, TC4003.

Augier, R., Jolivet, L., Do Couto, D., Negro, F., 2013. From ductile to brittle, late- to postorogenic evolution of the Betic Cordillera: structural insights from the northeastern internal zones. Bull. Soc. Geol. Fr. 184, 405-425.

Azdimousa, A., Bourgois, J., Poupeau, G., Vázquez, M., Asebriy, L., \& Labrin, E. (2014). Fission track thermochronology of the Beni Bousera peridotite massif (Internal Rif, Morocco) and the exhumation of ultramafic rocks in the Gibraltar Arc. Arabian Journal of Geosciences, 7(5), 1993-2005.

Azdimousa, A., Jabaloy-Sánchez, A., Talavera, C., Asebriy, L., González-Lodeiro, F., \& Evans, N. J. (2019). Detrital zircon U-Pb ages in the Rif Belt (northern Morocco): Paleogeographic implications. Gondwana Research, 70, 133-150. 
Bailey, S.W., 1980. Structure of layer silicates. In: Brindley, G.W., Brown, G. (Eds.), Crystal Structure of Clay Minerals and their X-ray Identification. MineralogicalSociety, London, pp. $1-124$.

Berthonneau, J., Grauby, O., Ferrage, E., Vallet, J. M., Bromblet, P., Dessandier, D., Chaudanson, D., Baronnet, A., 2014. Impact of swelling clays on the spalling decay of building limestones: insights from X-ray diffraction profile modeling. European Journal of Mineralogy, 26(5), 643-656.

Brindley, G.W., 1980. Order-disorder in clay mineral structures. In: Brindley, G.W., Brown, G. (Eds.), Crystal Structure of Clay Minerals and their X-ray Identification. Mineralogical Society, London, pp. 125-196.

Booth-Rea, G., Azañon, J.M., Martinez-Martinez, J.M., Vidal, O., Garcia-Dueñas, V., 2005. Contrasting structural and P-T evolution of tectonic units in the southeastern Betics: key for understanding the exhumation of the Alboran Domain HP/LT crustal rocks (western Mediterranean). Tectonics 24, TC2009. http://dx.doi.org/10.1029/2004TC001640.

Bouillin, J. P., Durand-Delga, M., Gelard, J. P., Leikine, M., Raoult, J. F., Raymond, D., Vila, J. M., 1970. Définition d'un flysch massylien et d'un flysch maurétanien au sein des flyschs allochtones de l'Algérie. Comptes Rendus de l'Académie des Sciences, 270, 2249-2252.

Bourgois, J., Mauffret, A., Ammar, A., Demnati, A., 1992. Multichannel seismic dataimaging of inversion tectonics of the Alboran Ridge (Western MediterraneanSea). Geo-Marine Letters $12,117-122$.

Braga, J.C., Martin, J.M., Quesada, C., 2003. Patterns and average rates of lateNeogene-Recent uplift of the Betic cordillera, SE Spain. Geomorphology 50, 3-26.

Caine, J. S., Evans, J. P., Forster, C. B., 1996. Fault zone architecture and permeability structure. Geology, 24(11), 1025-1028.

Caine, J., Minor, S., 2009. Structural and geochemical characteristics of faulted sediments and inferences on the role of water in deformation, Rio Grande Rift, New Mexico. Geological Society of America Bulletin 121., 1325-1340. 
Calvert, A., Sandvol, E., Seber, D., Barazangi, M., Roecker, S., Mourabit, T., Vidal, F., Alguacil, G., Jabour, N., 2000. Geodynamic evolution of the lithosphere and upper mantle beneath the Alboran region of the western Mediterranean: constraints from travel time tomography. J. Geophys. Res. 105 (B5), 10,871-10,898.

Capella, W., Matenco, L., Dmitrieva, E., Roest, W. M., Hessels, S., Hssain, M., Kouwenhoven, T.J., van OOrschot, M, Sierro, F.J., Stow, D.A.V., Trabucho-Alexandre, J., Tulbure, M.A., de Weger, W., Yousfi, M.Z., Krijgsman, W., 2017. Thick-skinned tectonics closing the Rifian Corridor. Tectonophysics, 710, 249-265.

Casciello, E., Cosgrove, J., Cesarano, M., Romero, E., Queralt, I., Verges, J., 2011. Illitesmectite patterns in sheared Pleistocene mudstones of the Southern Appenines and their implications regarding the process of illitization: a multiscale analysis. Journal of Structural Geology 38, 172-182.

Chalouan, A., Saji, R., Michard, A., Bally, A.W., 1997. Neogene tectonic evolution of the Southwestern Alboran basin as inferred from seismic data off Morocco. AAPG Bull. Am. Assoc. Petr. Geol. 81, pp. 1161-1184.

Chalouan, A., Michard, A., Kadiri, Kh., Negro, F., Lamotte, D., Soto, I.J., Saddiqi, O., 2008. In: Michard, A., Saddiqi, O., Chalouan, A., Frizon de Lamotte, D. (Eds.), The Rif belt continental evolution: the geology of Morocco. Springer Berlin/Heidelberg, pp. 203-302.

Clauer, N., 2013. The K-Ar and 40Ar/39Ar methods revisited for dating fine-grained K-bearing clay minerals. Chemical Geology, 354, 163-185.

Cliff, G., Lorimer, G.W., 1975. The quantitative analysis of thin specimens. J. Microsc., 103, 203-207.

Comas, M.C., Soto, J.I., 1999. Brittle deformation in the metamorphic basement at site 976: implications for middle Miocene extensional tectonics in the western Alboran basin. Proc. Ocean Drill. Program Sci. Results 161, 331-344.

Comas, M.C., Platt, J.P., Soto, J.I., Watts, A.B., 1999. The origin and tectonic history of the Alboran basin: insights from leg 161 results. Proc. Ocean Drill. Program Sci. Results 161, 555580. 
Cornée, J. J., Münch, P., Melinte-Dobrinescu, M., Moussa, A. B., Quillévéré, F., Drinia, H., Azdimousa, A., Ouazani Touhami, A., Merzeraud, G., Fauquette, S., Corsini, M., Moissette, P., Feddi, N., 2014. The Early Pliocene reflooding in the Western Mediterranean: New insights from the rias of the Internal Rif, Morocco. Comptes Rendus Geoscience, 346(3-4), 90-98.

Cornée, J.J., h, P., Achalhi, M., Merzeraud, G., Azdimousa, A., Quillévéré, F., MelinteDobrinescu, M., Chaix, C., Ben Moussa, A., Lofi, J., Séranne, M., Moissette, P., 2016. The Messinian erosional surface and the early Pliocene reflooding in the Alboran Sea: new insights from the Boudinar basin, Morocco. Sediment. Geol. 333, 115-129.

Crespo-Blanc, A., Orozco, M., García-Dueñas, V., 1994. Extension versus compression during the Miocene tectonic evolution of the Betic chain. Late folding of normal fault systems. Tectonics 13, 78-88.

de Capoa, P., Di Staso, A., Perrone, V., Zaghloul, M. N., 2007. The age of the foredeep sedimentation in the Betic-Rifian Mauretanian units: a major constraint for the reconstruction of the tectonic evolution of the Gibraltar Arc. Comptes Rendus Geoscience, 339(2), 161-170.

Delvaux, D., and Sperner, B., 2003. New aspects of tectonic stress inversion with reference to the TENSOR program. Geological Society of London, Special Publication, 212(1), 75-100.

Dewey, J. F., 1988. Extensional collapse of orogens. Tectonics, 7(6), 1123-1139.

Do Couto, D., Gorini, C., Jolivet, L., Lebret, N., Augier, R., Gumiaux, C., d'Acremont A., Ammar A., Jabour H., Auxietre, J. L., 2016. Tectonic and stratigraphic evolution of the Western Alboran Sea Basin in the last 25 Myrs. Tectonophysics, 677, 280-311.

Dong, H., Hall, C. M., Peacor, D. R., Halliday, A. N., 1995. Mechanisms of argon retention in clays revealed by laser 40Ar-39Ar dating. Science, 267(5196), 355-359.

Drits, V.A., Weber, F., Salyn, A.L., Tsipursky, S.I., 1993. X-ray identification of one layer illite varieties: application to the study of illites around uranium deposits of Canada. Clay Clay Mineral. 41, 389-398.

Duvall, A., Clark, M., van der Pluijm, B., Li, C., 2011. Direct dating of Eocene reverse faulting in northeastern Tibet using Ar-dating of fault clays and low temperature thermochronometry. Earth and Planetary Science Letters 304, 520-526. 
El Bakili, A., Corsini, M., Chalouan, A., Münch, P., Romagny, A., Lardeaux, J. M., Azdimousa, A., 2020. Neogene polyphase deformation related to the Alboran Basin evolution: new insights for the Beni Bousera massif (Internal Rif, Morocco) Déformation polyphasée néogène liée à l'évolution du bassin d'Alboran: nouvelles données sur le massif de Beni Bousera (Rif interne, Maroc). Bulletin de la Société Géologique de France, 191(1).

El Kadiri, K., Chalouan, A., El Mrihi, A., Hlila, R., Lopez-Garrido, A.C., Sanz de Galdeano, C., Serrano, F., 2000. Descubrimiento del Burdigaliense (formacion Viñuela) en la cobertera Gomaride de Ceuta (Rif septentrional). Geogaceta 28, 43-46.

El Maz, A., Guiraud, M., 2001. Paragenèse à faible variance dans les métapélites de la série de Filali (Rif interne marocain): description, interprétation et conséquences géodynamiques. Bull. Soc. Geol. Fr. 172, 469-485.

El Ouaragli, B., Zaghloul, M. N., El Talibi, H., Somma, R., 2016. Tectono-sedimentary evolution of the Miocene Oued Dayr Formation (Ghomaride Complex, Internal Domain of the Maghrebian Rif Belt, Morocco). Arabian Journal of Geosciences, 9(15), 660.

Esteban, J.J., Tubia, J.M., Cuevas, J., Seward, D., Larionov, A., Sergeev, S., Navarro-Vilá, F., 2013. Insights into extensional events in the Betic Cordilleras, southern Spain: New fissiontrack and U-Pb SHRIMP analyses. Tectonophysics 603, 179-188.

Feinberg, H., Maaté, A., Bouhdadi, S., Durand-Delga, M., Maate, M., Magne, J., Olivier, P., 1990. Signification des dépôts de l'oligocène supérieur-miocène inférieur du Rif interne (Maroc), dans l'évolution géodynamique de l'Arc de Gibraltar. C. R. Acad. Sci. Paris 310, 14871495.

Gallagher, K., Charvin, K., Nielsen, S., Sambridge, M., Stephenson, J., 2009. Markovchain Monte Carlo (MCMC) sampling methods to determine optimal models, model resolution and model choice for Earth Science problems. Marine andPetroleum Geology 26, 525-535.

García-Dueñas, V., Balanyá, J.C., Martínez-Martínez, J.M., 1992. Miocene extensional detachments in the outcropping basement of the northern Alboran Basin (Betics) and their tectonic implications. Geo-Marine Letters 12, 88-95. 
Gautheron, C., Tassan-Got, L., Barbarand, J., Pagel, M., 2009. Effect of alpha-damage annealing on apatite (U-Th)/He thermochronology. Chemical Geology, 266(3-4), 157-170.

Gautheron, C., Tassan-Got, L., Ketcham, R. A., Dobson, K. J., 2012. Accounting for long alpha-particle stopping distances in (U-Th-Sm)/He geochronology: 3D modeling of diffusion, zoning, implantation, and abrasion. Geochimica et Cosmochimica Acta, 96, 44-56.

Guerrera, F., Martín-Martín, M., Perrone, V., Tramontana, M., 2005. Tectono-sedimentary evolution of the southern branch of the Western Tethys (Maghrebian Flysch Basin and Lucanian Ocean): consequences for Western Mediterranean geodynamics. Terra Nova, 17(4), $358-367$.

Haines, S. H., van der Pluijm, B. A., 2008. Clay quantification and Ar-Ar dating of synthetic and natural gouge: application to the Miocene Sierra Mazatán detachment fault, Sonora, Mexico. Journal of Structural Geology, 30(4), 525-538.

Haines, S. H., van der Pluijm, B. A., 2010. Dating the detachment fault system of the Ruby Mountains, Nevada: Significance for the kinematics of low-angle normal faults. Tectonics, 29(4).

Haines, S. H., van der Pluijm, B. A., 2012. Patterns of mineral transformations in clay gouge, with examples from low-angle normal fault rocks in the western USA. Journal of Structural Geology, 43, 2-32.

Hlila, R., Chalouan, A., El Kadiri, K., Sanz de Galdeano, C., Martín-Pérez, J.A., Serrano, F., López-Garrido, A.C., Maaté, A., Guerra-Merchán, A., 2008. New stratigraphic data of the Oligo-Miocenetransgressive cover of the Ghomaride units (Northern Internal Rif, Morocco): implications on Tectono-sedimentary evolution. Rev. Soc. Geol. Esp. 21 (1-2), 59-71.

Homonnay, E., Corsini, M., Lardeaux, J. M., Romagny, A., Münch, P., Bosch, D., Cenki-Tok, B., Ouazzani-Touhami, M., 2018). Miocene crustal extension following thrust tectonic in the Lower Sebtides units (internal Rif, Ceuta Peninsula, Spain): Implication for the geodynamic evolution of the Alboran domain. Tectonophysics, 722, 507-535.

Hurford, A.J., Platt, J.P., Carter, A., 1999. Fission-track analysis of samples from the Alboran Sea basement. Proc. Ocean Drill. Program Sci. Results 161, 295-300. 
Iribarren, L., Vergés, J., Fernàndez, M., 2009. Sediment supply from the Betic-Rif orogen to basins through Neogene. Tectonophysics 475, 68-84.

Jabaloy, A., Galindo-Zaldívar, J., González-Lodeiro, F., 1993. The Alpujárride-NevadoFilábride extensional shear zone, Betic Cordillera, SE Spain. J. Struct. Geol. 15, 555-569.

Janowski, M., Loget, N., Gautheron, C., Barbarand, J., Bellahsen, N., Van den Driessche, J., Babault J., Meyer, B. 2017. Neogene exhumation and relief evolution in the eastern Betics (SE Spain): insights from the Sierra de Gador. Terra Nova, 29(2), 91-97.

Johnson, C., Harbury, N., Hurford, A.J., 1997. The role of extension in the Miocene denudation of the Nevado-Filabride Complex, Betic Cordillera (SE Spain). Tectonics 16, 189-204.

Jolivet, L., Augier, R., Robin, C., Suc, J.P., Rouchy, J.M., 2006. Lithospheric-scale geodynamic context of the Messinian salinity crisis. Sediment. Geol. 188-189, 9-33.

Jolivet, L., Augier, R., Faccenna, C., Negro, F., Rimmele, G., Agard, P., Robin, C., Rossetti, F., Crespo-Blanc, A., 2008. Subduction, convergence and the mode of backarc extension in the Mediterranean region. Bull. Soc. géol. Fr. 179, 525-550.

Kelley, S.P., and Platt, J.P., 1999. Ar-Ar dating of biotite and muscovite from Alboran basement samples, site 976. Proc. Ocean Drill. Program Sci. Results 161, 301-305.

Koppers, A.A.P., 2002. ArArCALC—software for 40Ar/39Ar age calculations. Comput. Geosci. 28 (5), 605-619.

Kornprobst, J., 1974. Contribution a l'étude pétrographique et structurale de la zone interne du Rif (Maroc septentrional), Petrography and structure of the Rif inner area, northern Morocco. Notes Mém. Serv. Géol. Rabat 251, 256 p.

Laverret, E., Clauer, N., Fallick, A., Mercadier, J., Patrier, P., Beaufort, D., \& Bruneton, P., 2010. $\mathrm{K}-\mathrm{Ar}$ dating and $\delta 18 \mathrm{O}-\delta \mathrm{D}$ tracing of illitization within and outside the Shea Creek uranium prospect, Athabasca Basin, Canada. Applied Geochemistry, 25(6), 856-871.

Lee, J.-Y., Marti, K., Severinghaus, J.P., Kawamura, K., Yoo, H.S., Lee, J.B., and Kim, J.S., 2006, A redetermination of the isotopic abundances of atmospheric Ar: Geochimica et Cosmochimica Acta, v. 70, 4507-4512. 
Löbens, J., Bense, F.A., Wemmer, K., Dunk1, I., Costa, C.H., Layer, P. et al., 2011. Exhumation and uplift of the Sierras Pampeanas: preliminary implications from $\mathrm{K}-\mathrm{Ar}$ fault gouge dating and low-T thermochronology in the Sierra de Comechingones (Argentina). Int J Earth Sci (Geol Rundsch), 100, 671-694.

Lonergan, L., Platt, J. P., 1995. The Malaguide-Alpujárride boundary: a major extensional contact in the Internal Zone of the eastern Betic Cordillera, SE Spain. Journal of Structural Geology, 17(12), 1655-1671.

Luján, M., Crespo-Blanc, A., \& Balanyá, J.C., 2006. The Flysch Trough thrust imbricate (Betic Cordillera): A key element of the Gibraltar Arc orogenic wedge. Tectonics, 25 (6). doi:10.1029/2005TC001910

Martínez-Martínez, J.M., Azañón, J.M., 1997. Mode of extensional tectonics in the southeastern betics (SE Spain): implications for the tectonic evolution of the peri-Alboran orogenic system. Tectonics, 16, 205-225.

McDougall, I. and Harrison, T.M., 1999. Geochronology and Thermochronology by the 40Ar/39Ar Method, second ed. Oxford University Press.

Michard, A., Negro, F., Saddiqi, O., Bouybaouène, M., Chalouan, A., Montigny, R., Goffé,B., 2006. Pressure-temperature-time constraints on the Maghrebide mountain building: evidence from the Rif-Betic transect (Morocco, Spain), Algerian corre-lations, and geodynamic implications. Comptes Rendus Geoscience 338, 92-114.

Monié, P., Torres-Roldán, R.L., García-Casco, A., 1994. Cooling and exhumation of the Western Betic Cordilleras, 40Ar/39Ar thermochronological constraints on a collapsed terrane. Tectonophysics 238, 353-379.

Moore, D.M., Reynolds, R.C., 1989. Identification of mixed layered minerals. In: Moore, D.M., Reynolds, R.C. (Eds.), X-ray Diffraction and the Identification and Analyses of Clay Minerals. Oxford University Press, UK, pp. 241-269.

Moore, D.M., Reynolds, R.C., 1997. X-Ray Diffraction and the Identification and Analysis of Clay Minerals: Oxford University Press, New York. 
Morel, J.L., 1988. Evolution récente de l'orogène rifain et de son avant-pays depuis la fin de la mise en place des nappes (Rif-Maroc). Geodiffusion Memoire 4.

Parry, W. T., Bunds, M. P., Bruhn, R. L., Hall, C. M., Murphy, J. M., 2001. Mineralogy, 40Ar/39Ar dating and apatite fission track dating of rocks along the Castle Mountain fault, Alaska. Tectonophysics, 337(3-4), 149-172.

Pevear, D. R., 1999. Illite and hydrocarbon exploration. Proc. Natl Acad. Sci. 96, 3440-3446.

Platt, J.P., Vissers, R.L.M., 1989. Extensional collapse of thickened continental lithosphere. A working hypothesis for the Alboran Sea and Gibraltar Arc. Geology 17, 540-543.

Platt, J.P., Soto, J.I., Whitehouse, M.J., Hurford, A.J., Kelley, S.P., 1998. Thermal evolution, rate of exhumation, and tectonic significance of metamorphic rocks on the floor of the Alboran extensional basin, western Mediterranean. Tectonics 17, 671-689.

Platt, J.P., Argles, T.W., Carter, A., Kelley, S.P., Whitehouse, M.J., Lonergan, L., 2003. Exhumation of the Ronda peridotite and its crustal envelope: constraints from thermal modelling of a P-T-time array. Journal of the Geological Society of London 160, 655-676.

Platt, J.P., Kelly, S.P., Carter, A., Orozco, M., 2005. Timing of tectonic events in the Alpujárride Complex, Betic Cordillera, southern Spain. Journal of the Geological Society of London 162, 451-462.

Platt, J.P., Behr, W.M., Johanesen, K., Williams, J.R., 2013. The Betic-Rif arc and its orogenic hinterland: a review. Annu. Rev. Earth Planet. Sci. 41, 313-357.

Rahl, J., Haines, S., van der Pluijm, B., 2011. Links between orogenic wedge deformation and erosional exhumation: evidence from illite age analysis of fault rock and detrital thermochronology of syn-tectonic conglomerates in the Spanish Pyrenees. Earth and Planetary Science Letters 307, 180-190.

Renne, P.R., Balco, G., Ludwig, K.R., Mundil, R., and Min, K., 2010. Joint determination of $40 \mathrm{~K}$ decay constants and $40 \mathrm{Ar} \cdot 40 \mathrm{~K}$ for the Fish Canyon sanidine standard, and improved accuracy for 40Ar/39Ar geochronology. Geochimica et Cosmochimica Acta, v. 74, 5349-5367. 
Ring, U., Uysal, I. T., Glodny, J., Cox, S. C., Little, T., Thomson, S. N., Stübner, K., Bozkaya, Ö., 2017. Fault-gouge dating in the Southern Alps, New Zealand. Tectonophysics, 717, 321338.

Romagny, A., Münch, P., Cornée, J. J., Corsini, M., Azdimousa, A., Melinte-Dobrinescu, M. C., Drinia, H., Bonno, M., Arnaud, N., Monié, P., Quillévéré, F., Ben Moussa, A., 2014. Late Miocene to present-day exhumation and uplift of the Internal Zone of the Rif chain: insights from low temperature thermochronometry and basin analysis. Journal of Geodynamics, 77, 3955.

Rossetti, F., Faccenna, C., Crespo-Blanc, A., 2005. Structural and kinematic constraints to the exhumation of the Alpujárride Complex (Central Betic Cordillera, Spain). J. Struct. Geol. 27, 199-216.

Ruiz Cruz, M.D., Sanz de Galdeano, C., 2012a. Possible genetic relationships between granulites and orthogneisses from Ceuta (Spain): geotectonic implications. Geotemas 13, 10961099.

Sanz de Galdeano, C., Vera, J.A., 1992. Stratigraphic record and palaeogeographical context of the Neogene basins in the Betic Cordillera, Spain. Basin Res. 4, 21-36.

Serrano, F., Sanz de Galdeano, C., El Kadiri, K., Guerra-Merchan, A., Lopez-Garrido, A.C., Martın-Martın, M., Hlila, R., 2006. Oligocene-early Miocene transgressive cover of the BeticRif Internal Zone.Revision of its geologic significance. Eclogae Geologicae Helvetiae 99, 237253.

Siebel, W., Hann, H.P., Danišík, M., Shang, C.K., Berthold, Ch., R ～er, J., Wemmer, K., Evans, N.J., 2010. Age constraints on faulting and fault reactivation: a multi-chronological approach: International Journal of Earth Sciences, 99(6), 1187-1197.

Sinclair, H., Gibson, M., Naylor, M., Morris, R., 2005. Asymmetric growth of the Pyrenees revealed through measurement and modeling of orogenic fluxes. American Journal of Science $305,369-406$. 
Sissingh,W., 2008. Punctuated Neogene tectonics and stratigraphy of the African-Iberian plateboundary zone: concurrent development of Betic-Rif basins (Southern Spain, Northern Morocco). Neth. J. Geosci. 87, 241-289.

Smith, P. E., Evensen, N. M., York, D., 1993. First successful 40Ar-39Ar dating of glauconies: Argon recoil in single grains of cryptocrystalline material. Geology 21, 41-44.

Solum, J., van der Pluijm, B., Peacor, D., 2005. Neocrystallization, fabrics and age of clay minerals from an exposure of the Moab Fault, Utah. Journal of Structural Geology 27, 15631576.

Srodon, J., Eberl, D.D., 1987. Illites. In: Bailey, S.W. (Ed.), Reviews in Mineralogy 12. Micas, pp. 495-544.

Suades, E., Comas M., Crespo-Blanc, A., 2013. Tectonic evolution of the Malaga Basin (Alboran Sea): insights from its sedimentary infill. Geogaceta 54, 87-90.

Tagami, 2012. Thermochronological investigation of fault zones. Tectonophysics 538-540, 6785 .

Tsukamoto, S., Tagami, T., Zwingmann, H., 2020. In: Tanner, D., Brandes, C. (Eds) Understanding Faults: Detecting, Dating, and Modeling. Elsevier, pp. 257-282.

van der Pluijm, B., Hall, C., Vrolijk, P., Pevear, D., Covey, M., 2001. The dating of shallow faults in the Earth's crust. Nature 412, 172-174.

Vázquez, M., Jabaloy, A., Barbero, L., Stuart, F.M., 2011. Deciphering tectonic- and erosion driven exhumation of the Nevado-Filabride Complex (Betic Cordillera, Southern Spain) by low temperature thermochronology. Terra Nova 23, 257-263.

Velde, B., 1965. Experimental determination of muscovite polymorph stabilities. Am. Mineral. $50,436-499$.

Viola, G., Scheiber, T., Fredin, O., Zwingmann, H., Margreth, A., Knies, J., 2016. Deconvoluting complex structural histories archived in brittle fault zones. Nature Communications, 7:13448. DOI: 10.1038/ncomms 13448 
Vissers, R.L.M., 2012. Extension in a convergent tectonic setting: a lithospheric view on the Alboran system of SW Europe. Geologica Belgica 15/1-2, 53-72.

Watts, A.B., Platt, J.P., Buhl, P., 1993. Tectonic evolution of the Alboran Sea basin. Basin Res. $5,153-177$.

Wibberley, C. A. J., Yielding, G., Di Toro, G., 2008. In: Wibberley, C. A. J., Kurz, W., Imber, J., Holdsworth, R. E., Collettini, C. (Eds). The Internal Structure of Fault Zones: Implications for Mechanical and Fluid-Flow Properties. 299, pp. 5-33.

Wu, L., Monié, P., Wang, F., Lin, W., Ji, W., Bonno, M., Münch, P. Wang, Q. 2016. Cenozoic exhumation history of Sulu terrane: Implications from (U-Th)/He thermochrology. Tectonophysics, 672-673, 1-15. https ://doi.org/10.1016/j.tecto.2016.01.035

Yaglan, R.F., Kim C.S., Pevear, D.R., Vrolijk, P.J. 2002; Illite polytype quantification for accurate K-Ar age determination. American Mineralogist, Volume 87, pages 1536-1545.

Zaghloul, M.N., Di Staso, A., Hlila, R., Perrone, V., Perrotta, S., 2010. The Oued Dayr Formation: first evidence of a new Miocene late-orogenic cycle on the Ghomaride complex (internal domains of the Rifian Maghrebian Chain, Morocco). Geodin. Acta 23, 185-194.

Zviagina, B.B., Sakharov, B.A., Drits, V.A., 2007. X-ray diffraction criteria for the identification of trans-and cis-vacant varieties of dioctahedral micas. Clays and Clay Minerals, $55(5), 467-480$.

Zwingmann, H., Mancktelow, N., 2004. Timing of Alpine fault gouges. Earth Planet. Sci. Lett. $223,415-425$.

Zwingmann, H., Mancktelow, Antognini M., Lucchini, R., 2010a. Dating of shallow faults: new constraints from the AlpTransit tunnel site (Switzerland). Geology 38, 487-490.

Zwingmann, H., Yamada, K., Tagami, T., 2010b. Timing of brittle deformation within the Nojima fault zone, Japan. Chem. Geol. 275, 176-185.

\section{Figure caption}


Figure 1. Geological and tectonic map of the Rif chain, western Mediterranean Sea (modified after Do Couto et al., 2016; Hlila et al., 2006 and Serrano et al., 2006). The inset map shows the location of the Tell, Rif and Betic fold and thrust belts in the western Mediterranean. WAB: West Alboran Basin.

Figure 2. Structural map and schematic cross section of the Ceuta peninsula (modified after Homonnay et al., 2018). CUU: Ceuta Upper Unit, MHLU: Monte Hacho Lower Unit. Location in Fig. 1. Fault gouge samples dated by ${ }^{40} \mathrm{Ar} /{ }^{39} \mathrm{Ar}$ (box), metamorphic rock samples used for apatite $\mathrm{U}-\mathrm{Th} / \mathrm{He}$ dating and micro-tectonic stations are localized. Paleostress tensors obtained from faults with kinematic criteria in the immediate vicinity of dated gouges are shown (yellow: CUU; pink: MHLU).

Figure 3. Field photographs of normal faults crosscutting metamorphic rocks from the Ceuta Upper Unit (A and B) and the Monte Hacho Lower Unit (C and D). A: fault core up to 1.5 meters thick (gouge sample CEU12-03); B: close view of foliated gouge, pen for scale (CEU1203); C: fault core, hammer for scale within white ellipse (gouge sample M10-30); D: thin (<5 $\mathrm{mm}$ ) gouge layer exhibiting slickensides (M10-29).

Figure 4. Selected XRD oriented patterns of clay mineral aggregates in Air Dried (AD: red continuous line) and Ethylene glycol solvated (EG: black dashed line) states of the four grainsize fractions for the CEU12-03 sample (CUU) and M10-29 (MHLU). Chlorite peaks (in grey): 14.1, 7.05 and $4.7 \AA$ in $\mathrm{AD}$ and EG. Illite peaks (in black): 9.96 and $4.98 \AA$ in $\mathrm{AD}$ and $\mathrm{EG}$. Interstratified R3 Illite/smectite peaks (bold number): 10.8 $\mathrm{A}$ in AD for (001) peak (with less than $10 \%$ in smectite layers). Smectite peak (italic number for M10-29 sample): $17.2 \AA$ in EG for (001) peak.

Figure 5. TEM images. A: clay particles from $<2 \mu \mathrm{m}$ fraction (sample M10-29), Mu: detrital Muscovite, I: authigenic Illite; B: (001) lattice-fringe image of muscovite from $<2 \mu \mathrm{m}$ fraction (sample M10-30); C: (001) lattice-fringe image of mixed layer illite/smectite crystal from $<0.5$ $\mu \mathrm{m}$ (sample M10-30); D: fluffy aggregates of idiomorphic mixed layer Illite/Smectite (I/S) crystals from $<0.5 \mu \mathrm{m}$ (sample M10-29); E: Idiomorphic illite (I) crystal from $<0.2 \mu \mathrm{m}$ fraction (sample M10-29), the arrow points to the EDX analysis spot; F: (001) lattice-fringe image of illite from $<0.2 \mu \mathrm{m}$ fraction (sample M10-29). 
Figure 6. Chemical compositions (TEM-EDX microanalyses) of individual clay particles from the $<0.2 \mu \mathrm{m}$ and $<2 \mu \mathrm{m}$ fractions in ternary diagram [Muscovite / Celadonite / Pyrophyllite] indicating respectively the tetrahedral charge, octahedral charge and non-charged minerals.

Figure 7. ${ }^{40} \mathrm{Ar}-{ }^{39} \mathrm{Ar}$ illite step-heating age spectra for vacuum-encapsulated clay gouge size fractions dated in CUU (samples CEU12-03, CEU12-15, SEB12-06) and MHLU (samples M10-29, M10-30).

Figure 8. Illite age analysis plot or plot of \% $2 \mathrm{M} 1$ (detrital illite) vs. ${ }^{40} \mathrm{Ar} /{ }^{39} \mathrm{Ar}$ illite Total Gas Ages (TGA) of the different clay-size fractions in samples CEU12-03, CEU12-15 and SEB1206 from CUU and in samples M10-29 and M10-30 from MHLU.

Figure 9. Thermal history of the Ceuta peninsula main units: Ceuta Upper Unit (CUU; Blue line) and Monte Hacho Lower Unit (MHLU; Red line). Inverse thermal modelling was computed with QTQt software (Gallagher, 2012) and Gautheron et al. (2009) diffusion parameters using ${ }^{40} \mathrm{Ar}-{ }^{39} \mathrm{Ar}$ of muscovite from both units as constraints (Homonnay et al., 2018). Dashed, light colored lines: $95 \%$ confidence interval of T-t paths. Blue and red shaded areas correspond to authigenic illite age range for MHLU and CUU. Inset shows the thermal history computed for AHe ages only.

Figure 10. Timing of main events in the tectonic evolution of the internal zones of the Rif-Betic chain and the Alboran Basin (based on Sanz de Galdeano and Vera, 1992; Comas et al., 1992, 1999; Crespo-Blanc et al., 1994; El Kadiri et al., 2005; Rossetti et al., 2005; Serrano et al., 2006; Hlila et al., 2008; Zaghloul et al., 2010; Augier et al., 2013; Cornée et al., 2014; Romagny et al., 2014; Do Couto et al., 2016; Homonnay et al., 2018). Plain arrow: ductile deformation; empty arrow: brittle deformation; red arrow: this study (dashed line: undated compressional deformation); black star: main subsidence event. CGG: Ciudad Granada Group, FF: Fnidek Formation, SAF : Sidi Abdeslam Formation, SU : Seismic Unit, VG : Viñuela Group.

Table 1. Results of XRD bulk mineralogy, clay mineralogy and polytype analyses.

Table 2. Results of ${ }^{40} \mathrm{Ar} /{ }^{39} \mathrm{Ar}$ dating

Table 3. Results of apatite U-Th/He dating. $[\mathrm{eU}]=[\mathrm{U}]+0.24 \times[\mathrm{Th}]$; Rs: spherical radius and Ft: ejection correction parameters, were calculated with flojt software (Gautheron et al., 2012). 


\begin{tabular}{|c|c|c|c|c|c|c|}
\hline & \multirow[t]{2}{*}{ Wall rock } & \multicolumn{5}{|c|}{ Gouge mineralogy \% } \\
\hline & & Quartz & Mica & Chlorite & Calcite & Albite \\
\hline SEB12-02 & CUU & 41 & 16 & 39 & 4 & nd \\
\hline CEU12-03 & CUU & 43 & 23 & 34 & nd & nd \\
\hline CEU12-15 & CUU & 71 & 16 & 13 & nd & nd \\
\hline M10-29 & MHLU & 66 & 19 & nd & nd & 15 \\
\hline \multirow[t]{3}{*}{ M10-30 } & MHLU & 88 & 12 & nd & nd & nd \\
\hline & & \multicolumn{3}{|c|}{$[1-2]$} & & \\
\hline & & $2 M_{1}$ & $1 M$ & Crystal size $\AA$ & & $2 M_{1}$ \\
\hline SEB12-02 & CUU & 10 & 90 & 232 & & 5 \\
\hline CEU12-03 & CUU & 70 & 30 & 370 & & 50 \\
\hline CEU12-15 & CUU & 20 & 80 & 226 & & 10 \\
\hline M10-29 & MHLU & 100 & 0 & 479 & & 70 \\
\hline M10-30 & MHLU & 70 & 30 & 384 & & 60 \\
\hline
\end{tabular}




\begin{tabular}{ccccc}
\multicolumn{5}{c}{ Clay fractions } \\
\hline Illite & Chlorite & $\begin{array}{c}\text { Illite / } \\
\text { Smectite } \\
\text { I/S }\end{array}$ & $\begin{array}{c}\text { Smectite } \\
\text { (S) }\end{array}$ & Calcite \\
$* * * *$ & $* *$ & $* *$ & & $* *$ \\
$* * * *$ & $* * *$ & & & \\
$* * * *$ & $* * *$ & $* *$ & & \\
$* * * *$ & $*$ & $*$ & $*$ & \\
$* * * *$ & & & &
\end{tabular}

\begin{tabular}{ccccccc}
\multicolumn{2}{l}{ ica polytypes \% } \\
\hline \multicolumn{1}{c}{$[0.5-1]$} & & \multicolumn{3}{c}{$[0.2-0.5]$} & \\
\cline { 4 - 6 } $1 M$ & Crystal size $\AA$ & & $2 M_{1}$ & $1 M$ & Crystal size $\AA$ & $2 M_{1}$ \\
95 & 189 & 0 & 100 & 113 & 0 \\
50 & 262 & 40 & 60 & 247 & 30 \\
90 & 143 & 0 & 100 & 74 & 0 \\
30 & 428 & 30 & 70 & 301 & 30 \\
40 & 375 & 30 & 70 & 333 & -
\end{tabular}




\begin{tabular}{cc}
\hline$<0.2$ & \\
\hline $1 M$ & Crystal size $\AA$ \\
100 & 98 \\
70 & 181 \\
100 & 98 \\
70 & 247
\end{tabular}




\begin{tabular}{|c|c|c|c|c|c|c|}
\hline Samples & 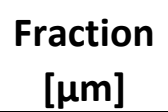 & $\begin{array}{c}\text { loss 39Ar } \\
{[\%]}\end{array}$ & [\%] & 2M1 & Ages & $2 \sigma$ \\
\hline \multirow{5}{*}{ CEU-12-03 } & $<0,2$ & 30.22 & 70 & 30 & 16.44 & 0.13 \\
\hline & $0,2-0,5$ & 21.45 & 60 & 40 & 17.64 & 0.09 \\
\hline & 0,5-1 & 17.07 & 50 & 50 & 24.83 & 0.11 \\
\hline & $1-2$ & 15.85 & 30 & 70 & 24.28 & 0.12 \\
\hline & bulk & 6.22 & - & - & 20.13 & 0.11 \\
\hline \multirow{5}{*}{ CEU-12-15 } & $<0,2$ & 17.9 & 100 & 0 & 18.02 & 0.08 \\
\hline & $0,2-0,5$ & 15.68 & 100 & 0 & 18.13 & 0.08 \\
\hline & $0,5-1$ & 13.18 & 90 & 10 & 19.19 & 0.08 \\
\hline & $1-2$ & 14.27 & 80 & 20 & 21.49 & 0.49 \\
\hline & bulk & 7.25 & - & - & 21.55 & 0.1 \\
\hline \multirow{5}{*}{ SEB-12-02 } & $<0,2$ & 32.59 & 100 & 0 & 15.83 & 0.69 \\
\hline & $0,2-0,5$ & 18.69 & 100 & 0 & 17.76 & 0.07 \\
\hline & $0,5-1$ & 13.7 & 95 & 5 & 18.99 & 0.09 \\
\hline & $1-2$ & 11.93 & 90 & 10 & 19.84 & 0.27 \\
\hline & bulk & 5.96 & - & - & 19.86 & 0.09 \\
\hline \multirow{5}{*}{$M-10-29$} & $<0,2$ & 32.08 & 70 & 30 & 15.30 & 0.08 \\
\hline & $0,2-0,5$ & 25.28 & 70 & 30 & 18.61 & 0.13 \\
\hline & $0,5-1$ & 20.53 & 30 & 70 & 20.25 & 0.27 \\
\hline & $1-2$ & 15.12 & 0 & 100 & 19.54 & 0.49 \\
\hline & bulk & 6.52 & - & - & 22.05 & 0.09 \\
\hline \multirow{5}{*}{$M-10-30$} & $<0,2$ & - & - & - & - & - \\
\hline & $0,2-0,5$ & 28.74 & 70 & 30 & 14.59 & 0.08 \\
\hline & $0,5-1$ & 25.84 & 50 & 50 & 15.40 & 0.08 \\
\hline & $1-2$ & 10.84 & 40 & 60 & 20.16 & 0.1 \\
\hline & bulk & 8.56 & - & - & 20.88 & 0.08 \\
\hline
\end{tabular}




\begin{tabular}{|c|c|c|c|c|c|c|}
\hline Sample & Unit & $\begin{array}{l}238 U \\
(\mathrm{ppm})\end{array}$ & $\begin{array}{l}\text { 232Th } \\
\text { (ppm) }\end{array}$ & $\begin{array}{c}4 \mathrm{He} \\
(\mathrm{nmol} / \mathrm{g})\end{array}$ & Th/U & [eU] (ppm) \\
\hline \multirow[t]{4}{*}{ M10-32 } & MHLU & 45.06 & 4.09 & 4.4 & 0.09 & 46.02 \\
\hline & & 30.5 & 3.61 & 3.4 & 0.12 & 31.35 \\
\hline & & 19.08 & 2.6 & 2.14 & 0.14 & 19.6 \\
\hline & & 58.69 & 3.03 & 5.24 & 0.05 & 26.5 \\
\hline \multirow[t]{4}{*}{ M10-31 } & MHLU & 21.93 & 2.23 & 2.12 & 0.1 & 22.46 \\
\hline & & 19.69 & 2.82 & 2.08 & 0.15 & 20.36 \\
\hline & & 31.79 & 6.58 & 2.77 & 0.21 & 33.34 \\
\hline & & 24.8 & 7.23 & 2.29 & 0.3 & 26.5 \\
\hline \multirow[t]{5}{*}{ CEU12-11 } & CUU & 23.91 & 0.51 & 2.36 & 0.02 & 24.03 \\
\hline & & 22.68 & 0.84 & 2.42 & 0.04 & 22.88 \\
\hline & & 50.81 & 1.99 & 4.86 & 0.04 & 51.27 \\
\hline & & 51.9 & 23.23 & 4.54 & 0.46 & 57.36 \\
\hline & & 72.62 & 1.85 & 5.7 & 0.03 & 73.06 \\
\hline \multirow[t]{3}{*}{ SEB12-06 } & CUU & 21.81 & 4.24 & 1.58 & 0.2 & 22.81 \\
\hline & & 5.61 & 2.78 & 0.4 & 0.51 & 6.26 \\
\hline & & 77.58 & 25.02 & 4.96 & 0.33 & 83.46 \\
\hline
\end{tabular}




\begin{tabular}{cccccc}
\hline Rs $(\mu \mathrm{m})^{*}$ & Age (Ma) & error $(2 \sigma, \mathrm{Ma})$ & $\mathrm{Ft}^{*}$ & $\begin{array}{c}\text { Corrected Age } \\
(\mathrm{Ma})\end{array}$ & $\begin{array}{c}\text { Weighted Mean } \\
(2 \sigma, \mathrm{Ma})\end{array}$ \\
\hline 77 & 17.71 & 0.16 & 0.888 & 19.94 & \\
88.5 & 20.08 & 0.16 & 0.908 & 22.11 & \\
59.7 & 20.18 & 0.27 & 0.867 & 23.28 & \\
47.8 & 16.34 & 0.13 & 0.836 & 19.55 & \\
& & & & & $20.89+/-1.78$ \\
\hline 84.5 & 17.48 & 0.11 & 0.906 & 19.29 & \\
71.3 & 18.93 & 0.08 & 0.886 & 21.37 & \\
45.2 & 15.37 & 0.13 & 0.823 & 18.68 & \\
40 & 16.05 & 0.17 & 0.804 & 19.96 & \\
& & & & & \\
\hline 79.8 & 18.18 & 0.21 & 0.899 & 20.22 & \\
68.8 & 19.57 & 0.18 & 0.888 & 22.04 & \\
81.9 & 17.57 & 0.17 & 0.901 & 19.50 & \\
62.6 & 14.68 & 0.2 & 0.870 & 16.87 & \\
81.5 & 14.47 & 0.11 & 0.901 & 16.06 & \\
& & & & & $18.62+/-2.46$ \\
\hline 74 & 12.88 & 0.13 & 0.893 & 14.42 & \\
69.2 & 11.88 & 0.14 & 0.885 & 13.42 & \\
50.4 & 11.02 & 0.13 & 0.725 & 15.20 & \\
& & & & & \\
\hline
\end{tabular}




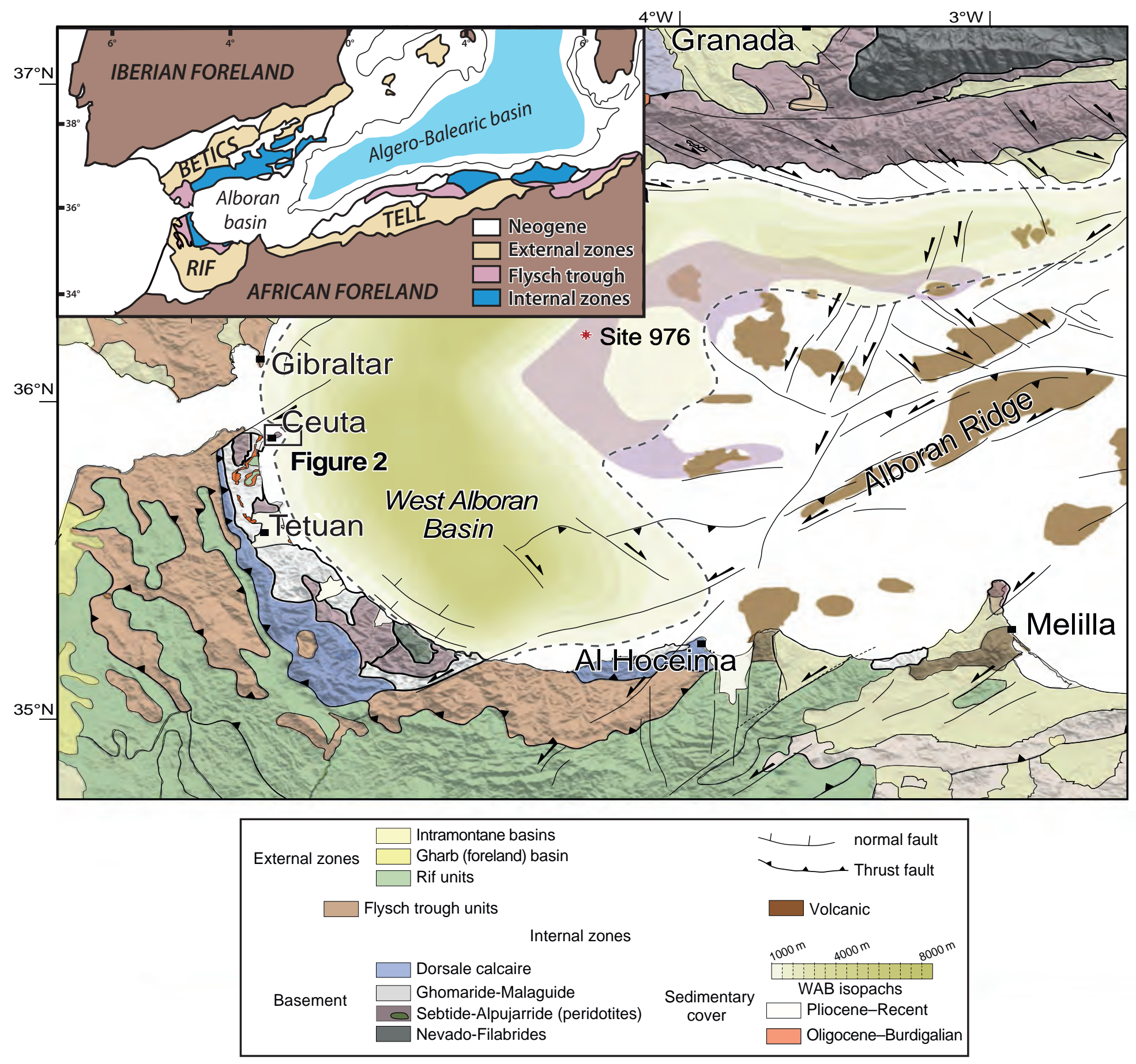

Figure 1. Geological and tectonic map of the Gibraltar arc, western Mediterranean sea (modified after Do Couto et al., 2016; Hlila et al., 2006 and Crespo-Blanc and Campos, 2001). The inset map shows the location of the Tell, Rif and Betic fold and thrust belts in the western Mediterranean. WAB: West Alboran Basin. 


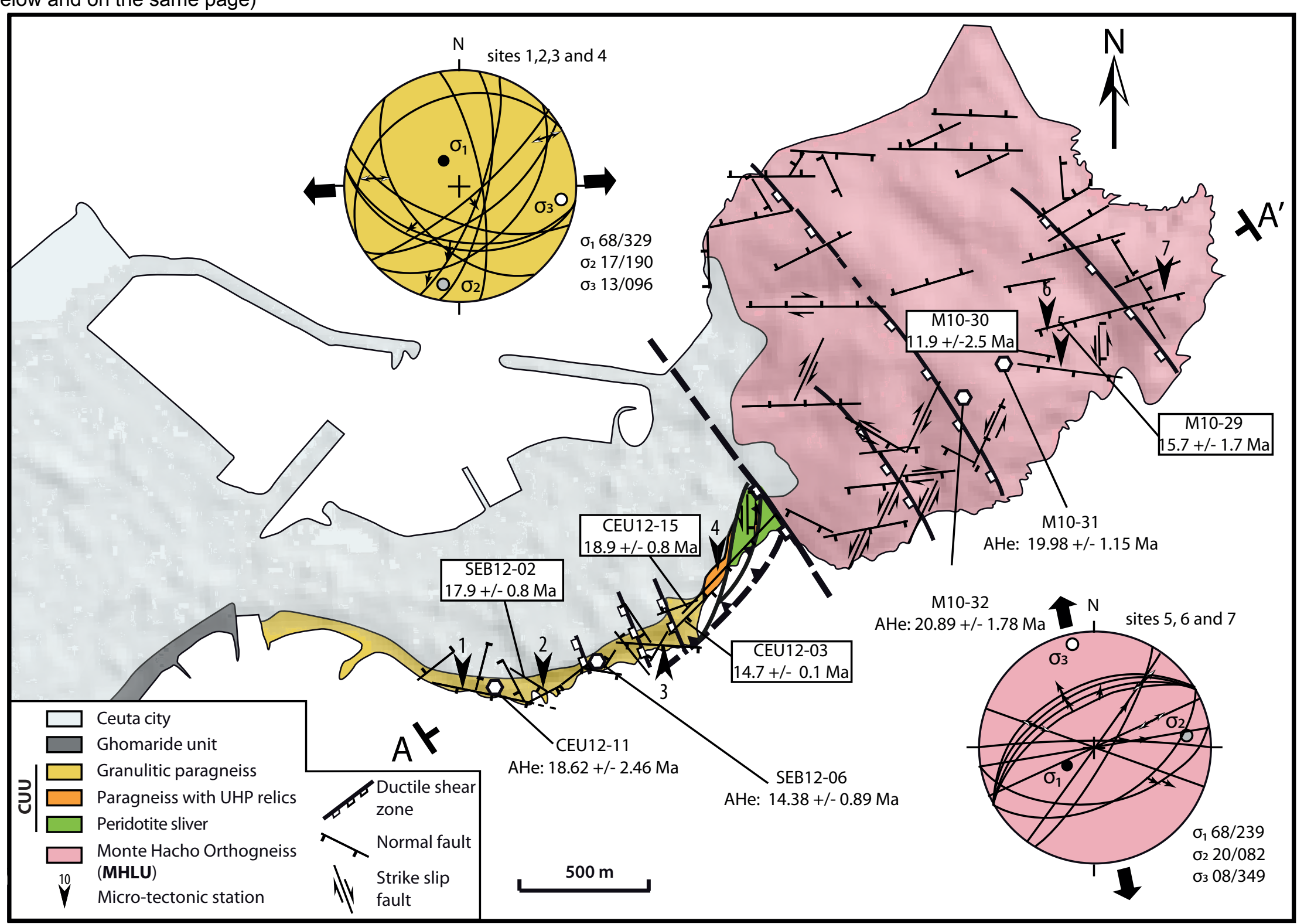

Figure 2.

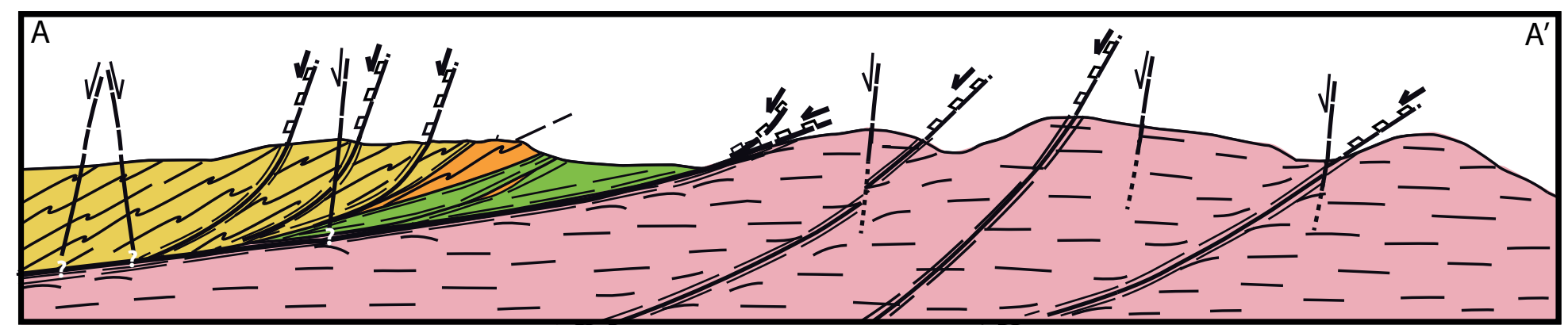



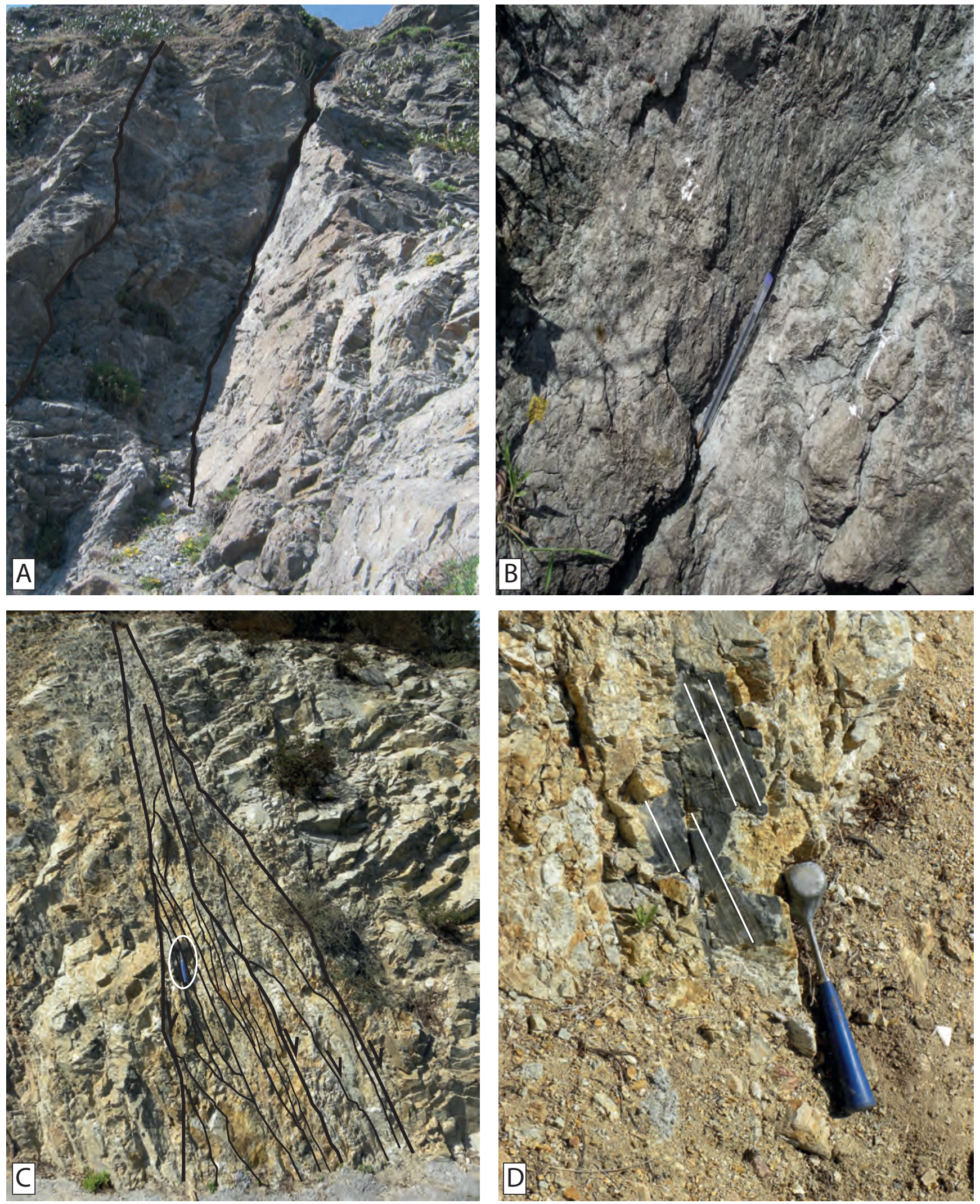

Figure 3. Field photographs of normal faults within the Ceuta Upper Unit ( $A$ and $B$ ) and Monte Hacho Lower Unit (C and D). A: fault core up to 1.5 meters thick (gouge sample CEU12-03); B: close view of foliated gouge, pen for scale(CEU12-03); C: fault core, hammer for scale within white ellipse (gouge sample M10-30); D: thin (<5 mm) gouge layer exhibiting slickensides (M10-29). 


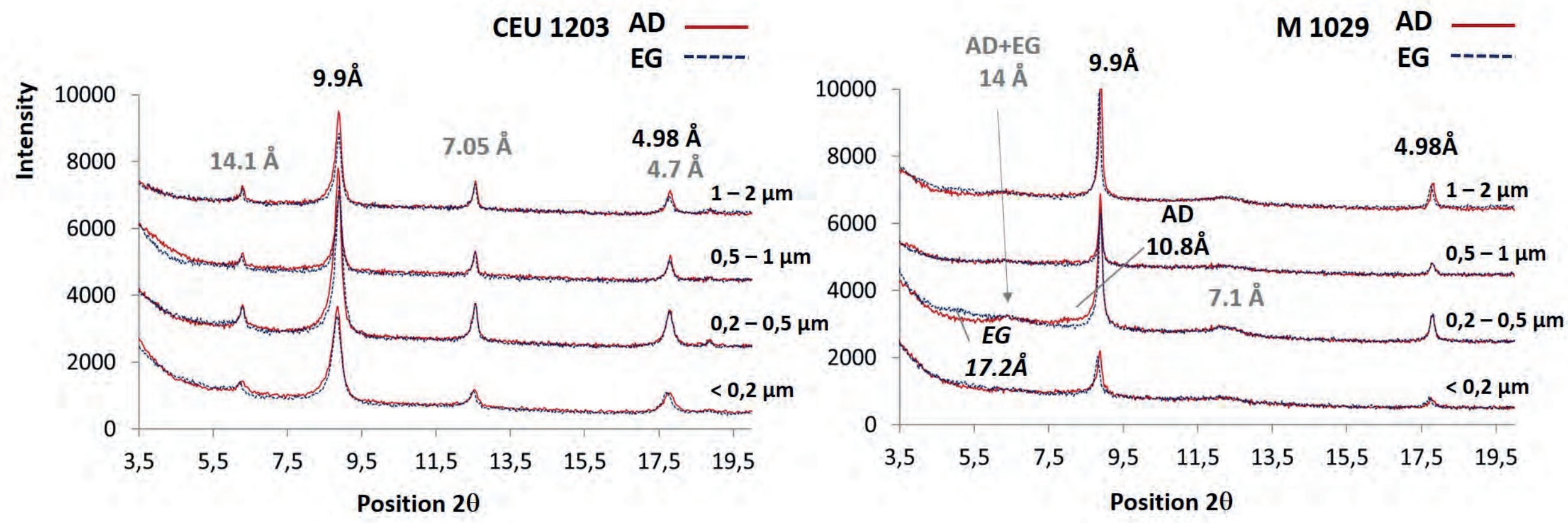

Figure 4. Selected XRD oriented patterns of clay mineral aggregates in Air Dried (AD: red continuous line) and Ethylene glycol solvated (EG: black dashed line) states of the four grain-size fractions for the CEU12-03 sample (CUU) and M10-29 (MHLU). Chlorite peaks (in grey): 14.1, 7.05 and 4.7 $\mathrm{A}$ in

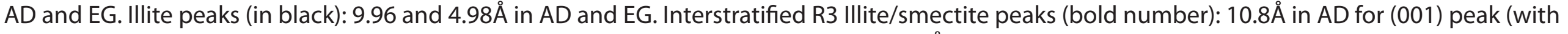
less than $10 \%$ in smectite layers). Smectite peak (italic number for M10-29 sample): $17.2 \AA$ in EG for (001) peak. 

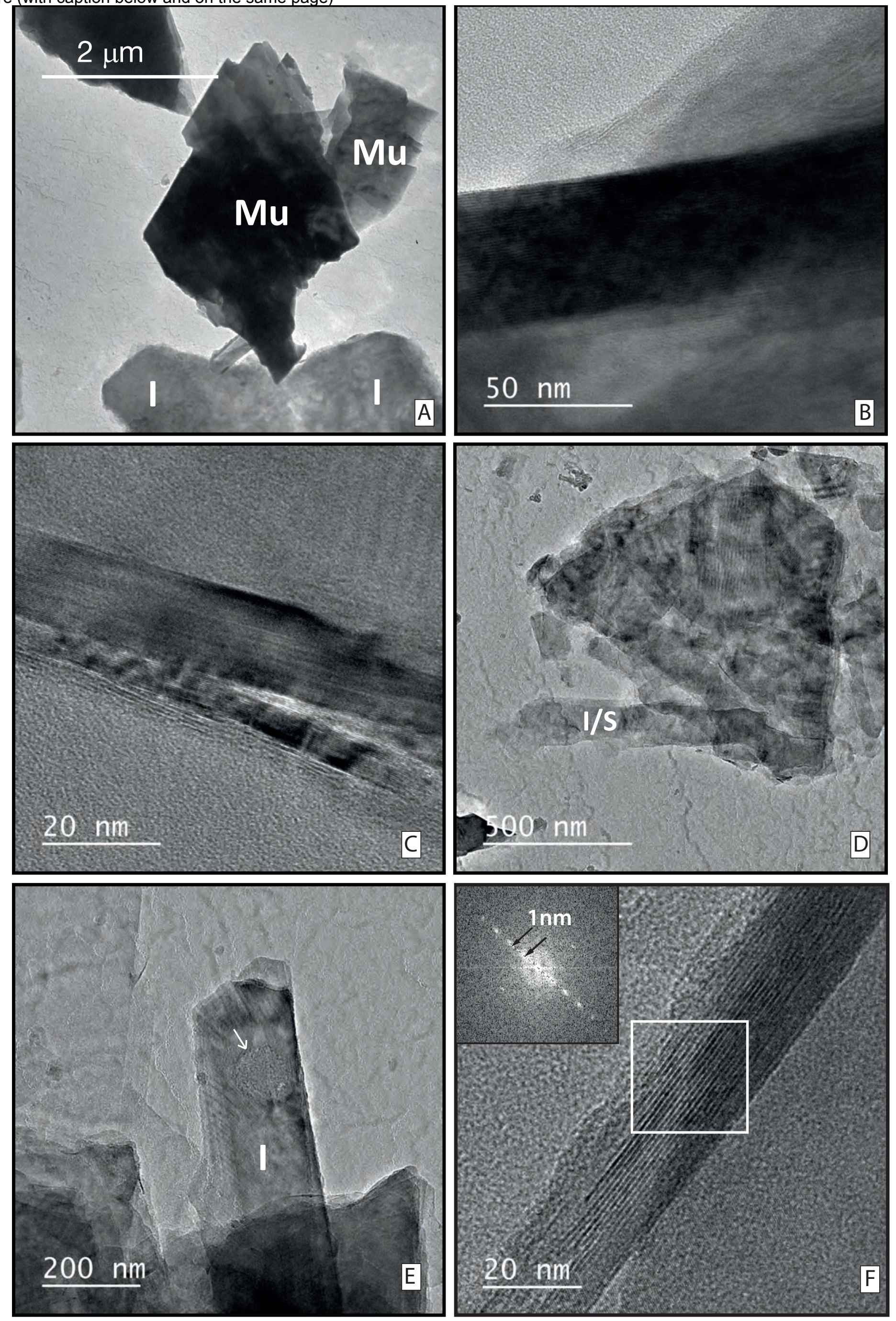

Figure 5. 


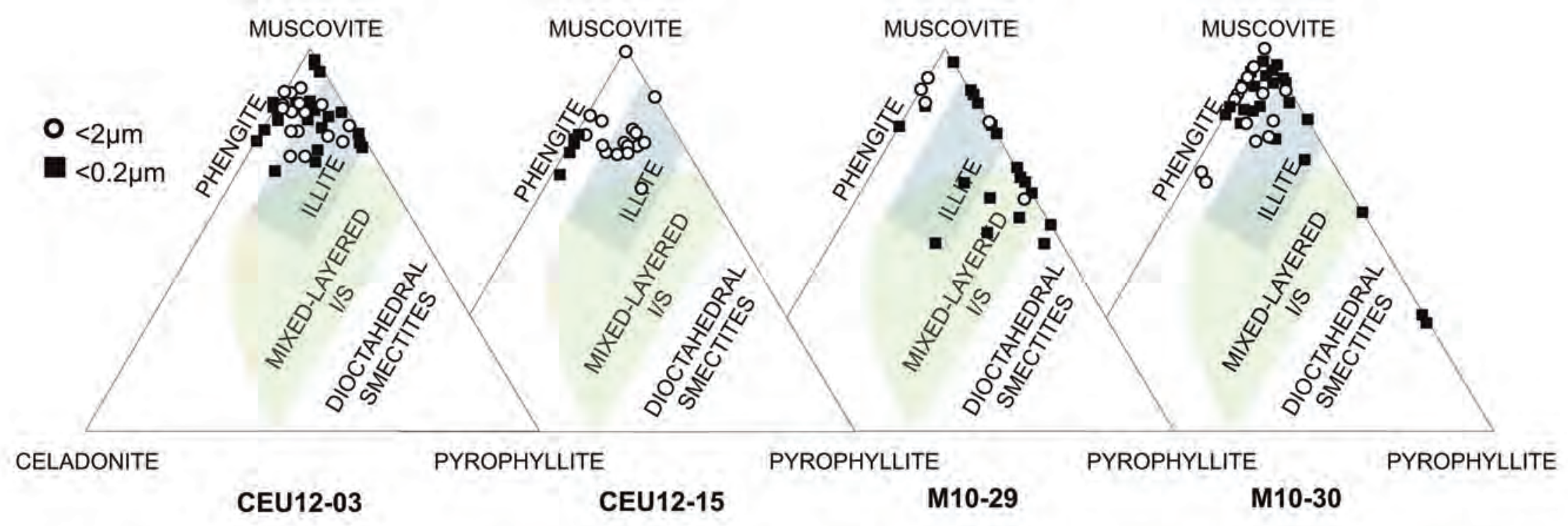

Figure 6. Chemical compositions (TEM-EDX microanalyses) of individual clay particles from the $<0.2 \mu \mathrm{m}$ and $<2 \mu \mathrm{m}$ fractions in ternary diagram [Muscovite / Celadonite / Pyrophyllite] indicating respectively the tetrahedral charge, octahedral charge and non-charged minerals. 
Figure (with caption below and on the same page)
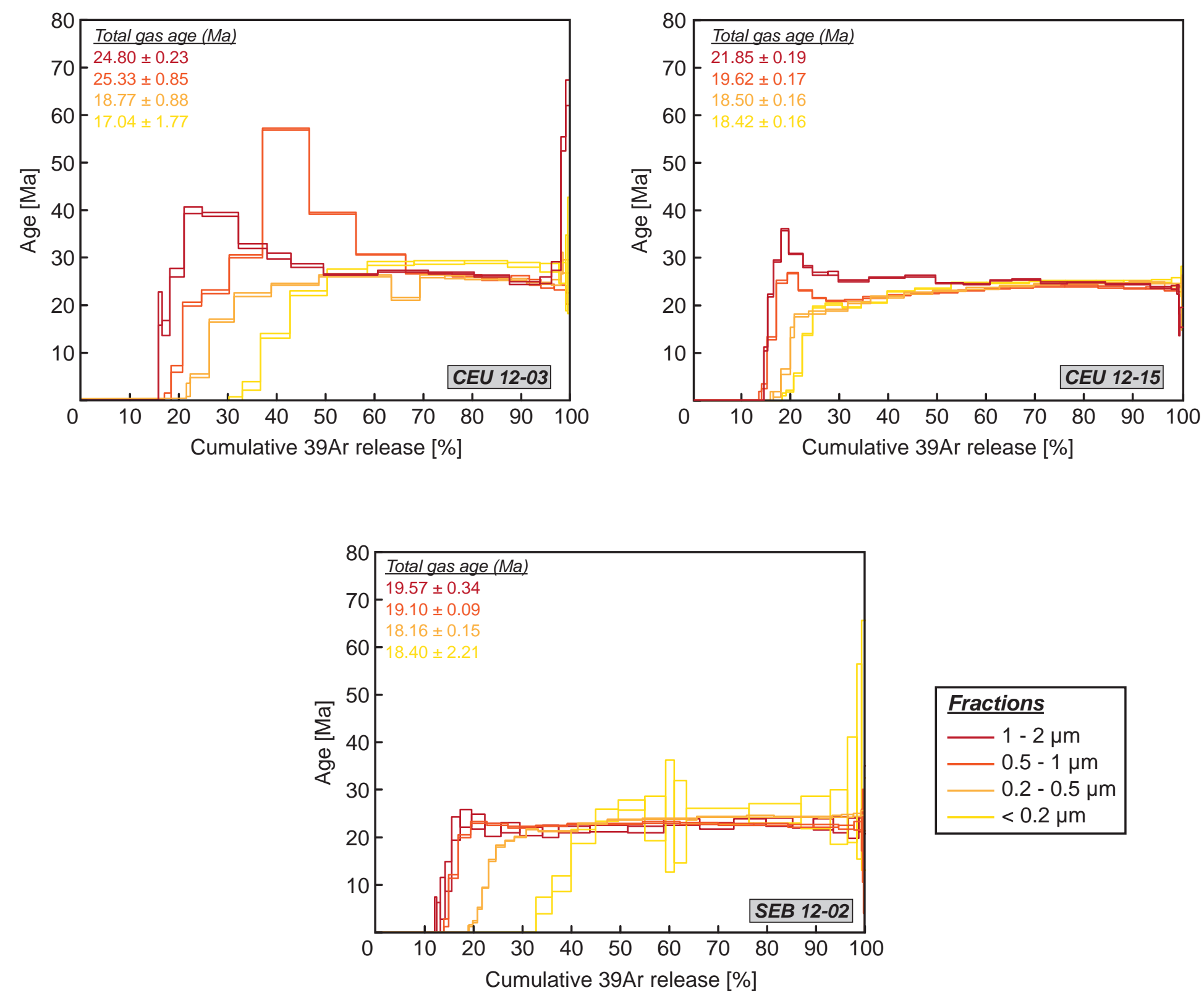

\section{Fractions}

1 - $2 \mu \mathrm{m}$

$0.5-1 \mu \mathrm{m}$

$0.2-0.5 \mu \mathrm{m}$

$<0.2 \mu \mathrm{m}$
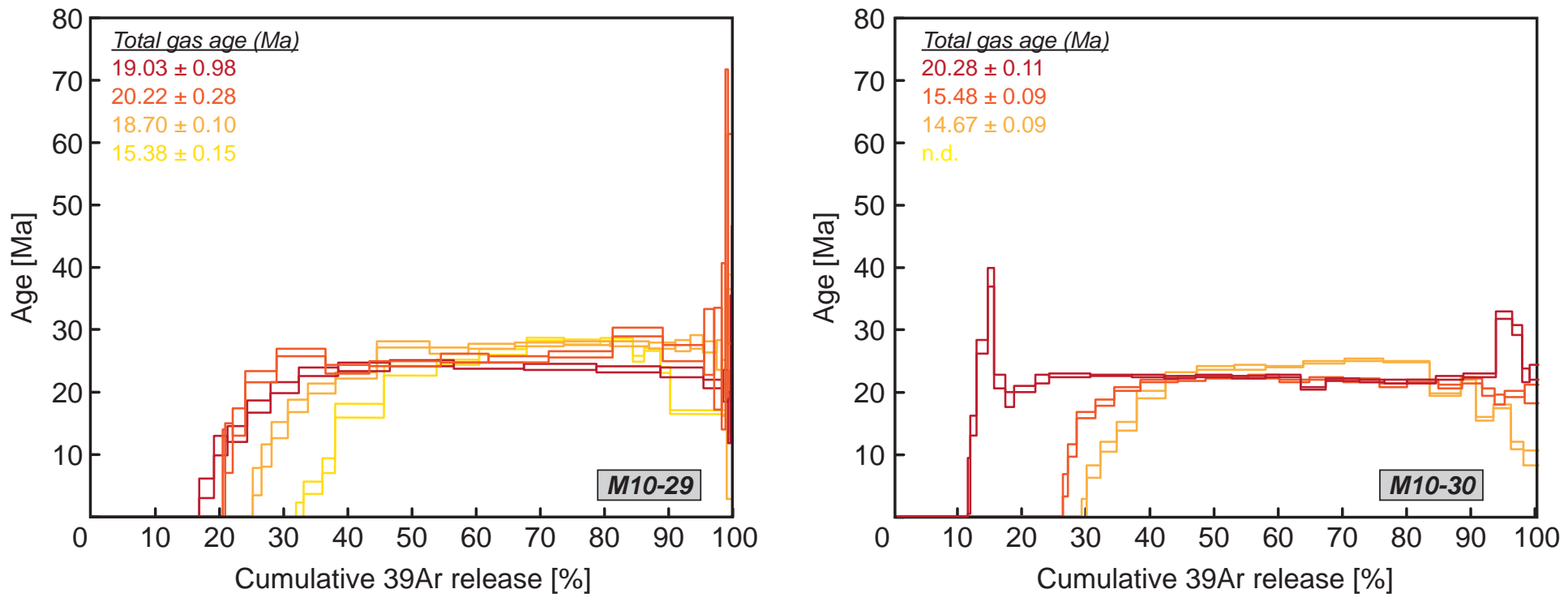

Figure 7. 
Ceuta Upper Unit
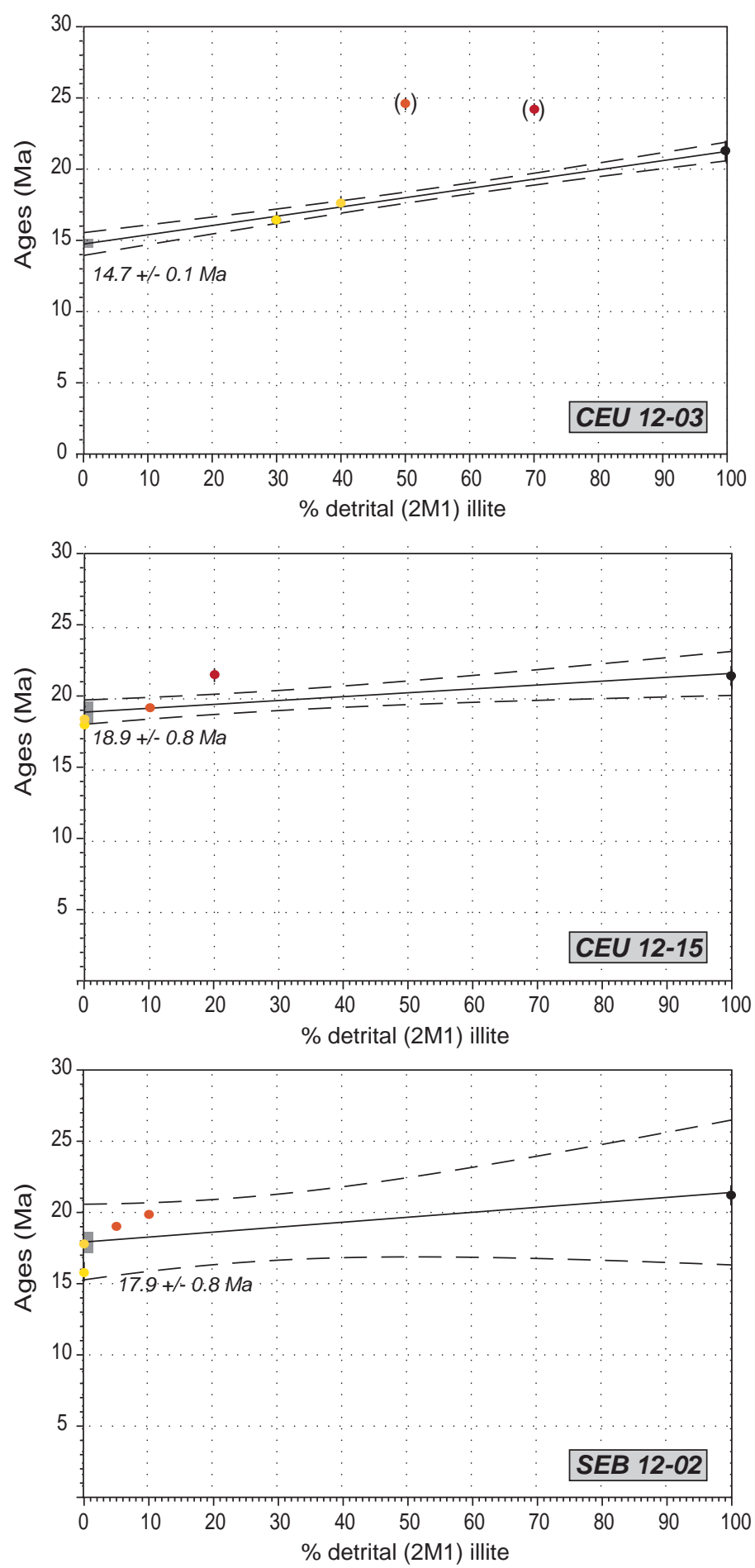

Monte Hacho Lower Unit
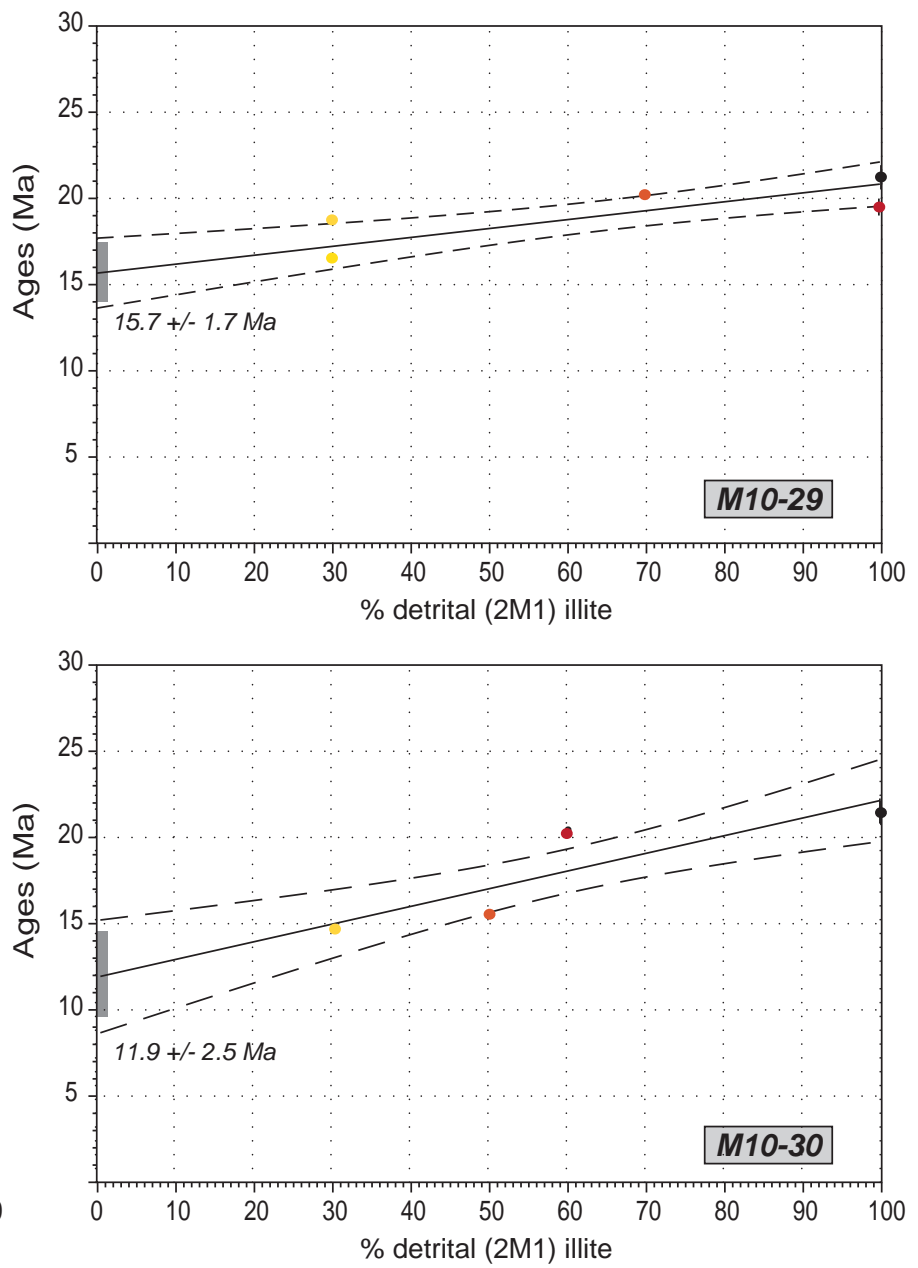

Figure 8. Illite age analysis plot or plot of \% 2M1 (detrital illite) vs. 40Ar/39Ar illite Total Gas Ages (TGA) of the different clay-size fractions in samples CEU12-03, CEU12-15 and SEB12-06 from CUU and in samples M10-29 and M10-30 from MHLU. 


\section{MHLU vs CUU Expected Tt paths}

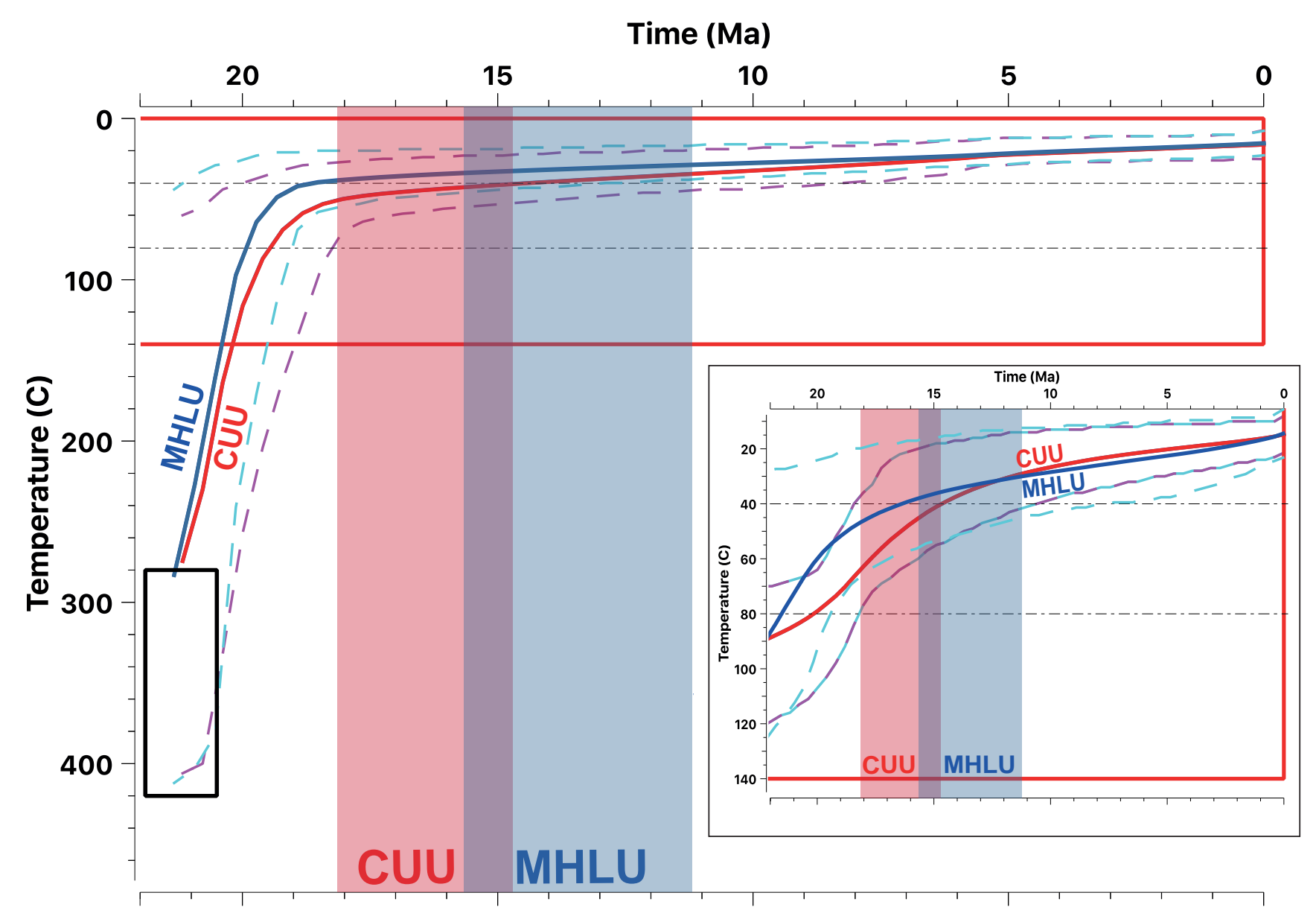

Figure 9. Thermal history of the Ceuta peninsula main units: Ceuta Upper Unit (CUU; Blue line) and Monte Hacho Lower Unit (MHLU; Red line). Inverse thermal modelling was computed with QTQt software (Gallagher, 2012) and Gautheron et al. (2009) diffusion parameters using 40Ar-39Ar of muscovite from both units (Homonnay et al., 2018). Dashed, light colored lines: 95\% confidence interval of T-t paths. Blue and red shaded areas correspond to authigenic illite age range for MHLU and CUU. Inset shows the thermal history computed for AHe ages only. 


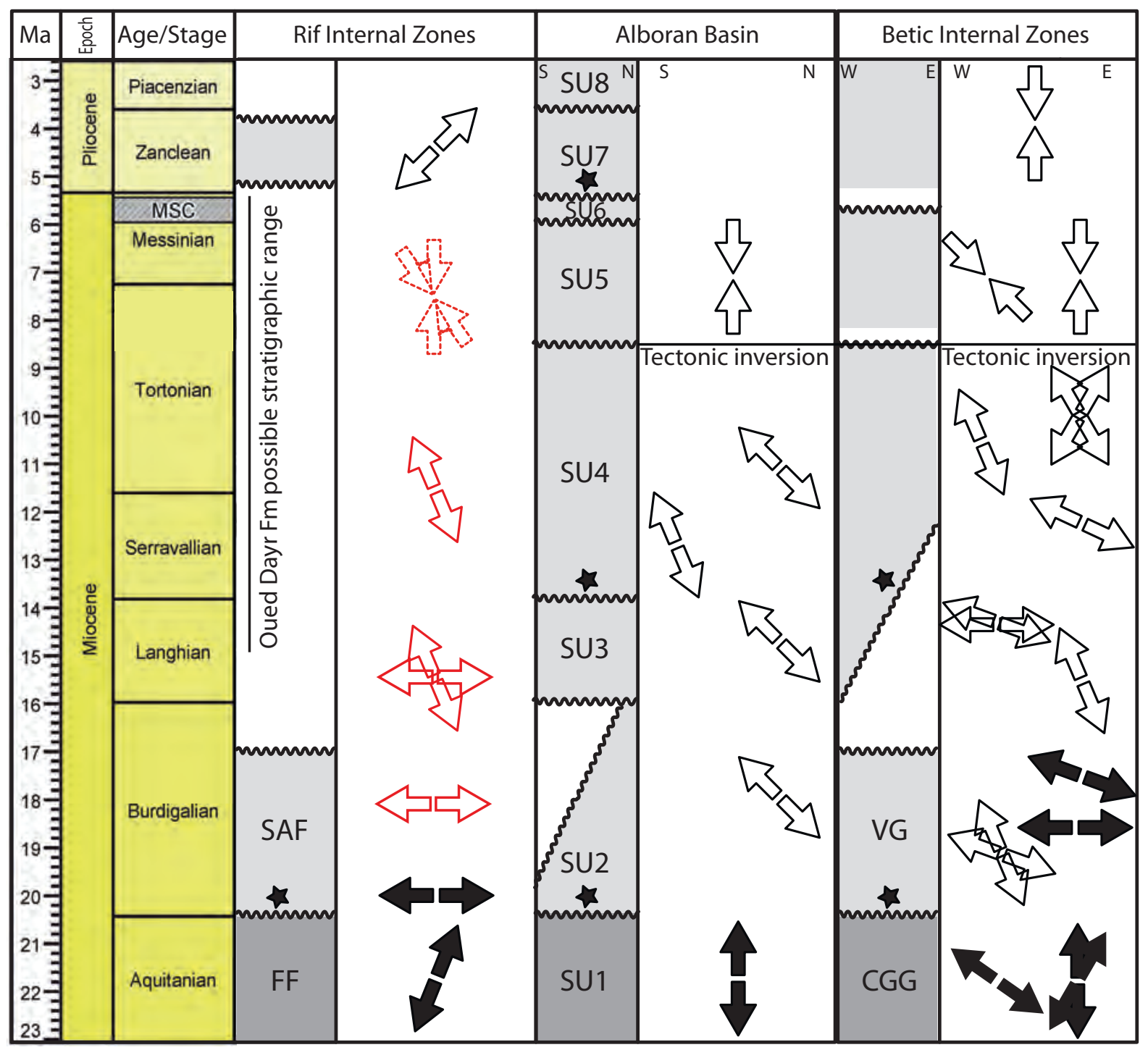

Figure 10. Timing of main events in the tectonic evolution of the internal zones of the Rif-Betic chain and the Alboran Basin (based on Sanz de Galdeano and Vera, 1992; Comas et al., 1992, 1999; Crespo-Blanc et al., 1994; El Kadiri et al., 2005; Rossetti et al., 2005; Serrano et al., 2006; Hlila et al., 2008; Zaghloul et al., 2010; Augier et al., 2013; Cornée et al., 2014; Romagny et al., 2014; Do Couto et al., 2016; Homonnay et al., 2018). Plain arrow: ductile deformation; empty arrow: brittle deformation; red arrow : this study (dashed line: undated deformation); black star: main subsidence event. CGG: Ciudad Granada Group, FF : Fnidek Formation, SAF : Sidi Abdeslam Formation, SU : Seismic Unit, VG : Vinuela Group. 